\title{
日本海における極気低気圧およびそれに 伴う沿岸平野部豪雪の解析
}

\author{
竹内 衛夫 ・内山 德栄

\section{Synoptic Analysis of Polar Lows over the Japan Sea Area and Heavy Snowfalls in the Coastal Plain Regions}

by

\author{
Morio Takeuchi \\ Yamagata Locol Meleorologicál Observatory, 990 Japan \\ Tokuei Uchiyama \\ Meteorological Research Institute, Tsukuba, Iboruki, 305 Japan
}

(Received March 30，1984; Revised Nov. 19, 1984)

\begin{abstract}
The results of synoptic analysis are described concerning the two typical examples of wintertime polar lows over the Japan Sea area. That occurred in the period of 24-27th FEB. 1981.

In this report, the following results are obtained.

(1). Non-frontal cyclones of small dimensions are' formed in polar air masses over the Japan Sea in winter. They are located on the forward sides of the positive vorticity maxima at $500 \mathrm{mb}$ and accompanied with a spiral or comma-shaped cloud pattern as they mature. They are also associated with the convectively neutral layers through a substantial depth of the troposphere and situated in regions marked by well-developed baroclinity throughout the troposphere in the poleward side of the jet stream. These features show that these cyclones are so-called polar lows.

(2). There are two-kinds of vorticity maxima at $500 \mathrm{mb}$. One is located in the central regions of cold vortex, and the other in the trough areas. The surface cyclones combined with the cold vortices are also of small dimensions below about $1000 \mathrm{~km}$ over the Japan Sea area and can be regarded as polar lows.

(3). The formation of deep layers of convective neutrality is investigated. It is shown by the stability change equation that the convectively neutrae layers of the middle troposphere between 700 and $500 \mathrm{mb}$ on the forward areas of the positive vorticity maxima at $500 \mathrm{mb}$ are mainly formed by the horizontal convergence effect, while in the rear areas of these maxima the layers are stabilized by the horizontal divergence effect. The layers below $700 \mathrm{mb}$ are destabilized by low-level heating over the oceans in winter. These two layers combine and form the convectively neutrae layers through a considerable depth of the troposphere in front of the upper positive vorticity maxima.

(4). Instability mechanism for the formation of these cyclones are discussed by using of Petterssen's development equation and the distributions of Richardson numbers. It is suggested that the baroclinity effect, including the influence of the vorticity advection in the upper atmosphere on the surface cyclogenesis, and the non-adiabatic effect in the atmosphere of small Richardson numbers below about 10 are the main cause of the formation of the cyclones of small size below about $1000 \mathrm{~km}$,
\end{abstract}


(5). The heavy snowfalls caused by the convective cloud bands accompanied with these polar lows in the coastal plain regions along the Japan Sea are also investigated. It is shown that the distributions of daily precipitation amounts are interpretable by the distributions of these convective cloud bands.

\section{1.はじめに}

主要前線帯の背後の全くの寒気団中に, 前線構 造の不明瞭な，スケールが $1000 \mathrm{~km}$ 程度の小さい 低気圧が下層に形成されることがしばしばある。 このような低気圧の存在は古くから知られてい る。全く寒気団の中にあって，前線がないか，あ るいは前線活動の弱いような低気圧は，例えば， back-bent occlusion cyclone または secondary low よ゙と云われてきた (Brunt, 1952; Huschke, 1959)。最近では英国の気象局の命名で Polar low あるいは Polar trough とよばれることが多い (Met. Office, 1962; Reed, 1979)。ここでは, 極気低気圧とよぶことにする。

1967年12月 7 日〜 9 日に，英国でこの種の低気 王が 2 個相ついで通過し，海岸地带に大雪を降ら せたために，多くの著者によって注目され，解 析, 研究された (Harrold and Browning, 1969; Mansfield, 1974, Stevenson, 1968; Duncan, 1977 ; Rasmussen, 1979 ; Фkland, 1977等)。

近年, 気象衛星の雲写真観測から, これらの低 気圧あるいは谷が，形が定っていない発達した積 雲の団塊一Enhanced Cumulus一あるいはコンマ 型等とよばれている対流雲のクラスターを伴って いることが見出され，主に海洋上で，スケールが比 較的小さい擾乱にもかかわらず, 日々の天気図解 析で良く検出されるようになってきた (Anderson et al., 1973; Reed, 1979等)。ここでは, Enhanced Cumulus を発達積雲群とよ゙ぶことにする。

極気低気压の成因については，最初は海面から の加熱による熱的低気圧と考兄られてきた（Met. Office, 1962等)。Harrold and Browning (1969) はドップラーレーダーの観測から, 対流雲の上昇 気流は数十 $\mathrm{cm}$ のオーダーのもので, 対流活動が 弱く，下層では弱い前線帯が存在していたことか ら，Eady (1949) の傾圧不安定理論で，擾乱のお よぶ層の厚さを薄くして，傾圧層を浅くすれば， この低気圧のよらな $1000 \mathrm{~km}$ 程度のスケールの 擾乱の発達が説明されると考えた。この観点は
Mansfield (1974) によっても支持された。一方, Rasmussen (1979) および Фkland (1977)は, 熱 帯低気圧同様, 対流による凝結の潜熱の放出によ る第 2 種条件付不安定機構によって発達する擾乱 であると論じている。

Duncan（1977）は，擾乱の及ぶ層が $300 \mathrm{mb}$ に届く程, 即ち傾圧場の厚さが 10 数 $\mathrm{km}$ に及ぶ ほど厚いとしても，静的安定度が悪ければ，この 低気圧程度の小さい擾乱が傾圧不安定理論で説明 されることを示した。 Reed (1979) は, 太平洋 の東部扣よびアメリカ西岸の極気低気珐を解析し て，擾乱の及ぶ高さが高いことを見出し，また明 らかに対流圏全体に特よぶよらな深い厚さを持っ た偏西風帯の傾圧場に位置していることから， Duncan の説を支持している。

この報告では, 冬期の日本海上で, 全くの寒気 団の中で発生しているスケールの小さい低気圧 6 例を解析して，これらの構造及び発生について調 ベた結果を述べている。解析を行ったのは次の 6 例であるが，ここでは，1981年2月24日〜27日の 2 例を中心として記述している。

1976年11月19日，11月28日

1977年 2 月 15 日，2 2 月 19 日

1978年 2 月16日 17 日

1981年 2 月 24 日 27 日

なお，1976年11月の 2 例については既に一部報 告した（竹内, 内山, 1979)。

\section{2. 事 例 解 析}

ここでは，1981年 2 月 24 日〜27日の例をとって 記述する。

\section{1 総観的記述}

\subsection{1 上層の状態}

$500 \mathrm{mb}$ の天気戍では，2 月中旬から，高圧部 がアラスカ拉よびシベリヤ中部で北に向って発達 し，北緯60度〜70度に達していた。上層の偏西風 帯に叔ける低気圧と高気圧の切離過程が進行して いて，2月24日09時には，第 1 図に見られるよう 

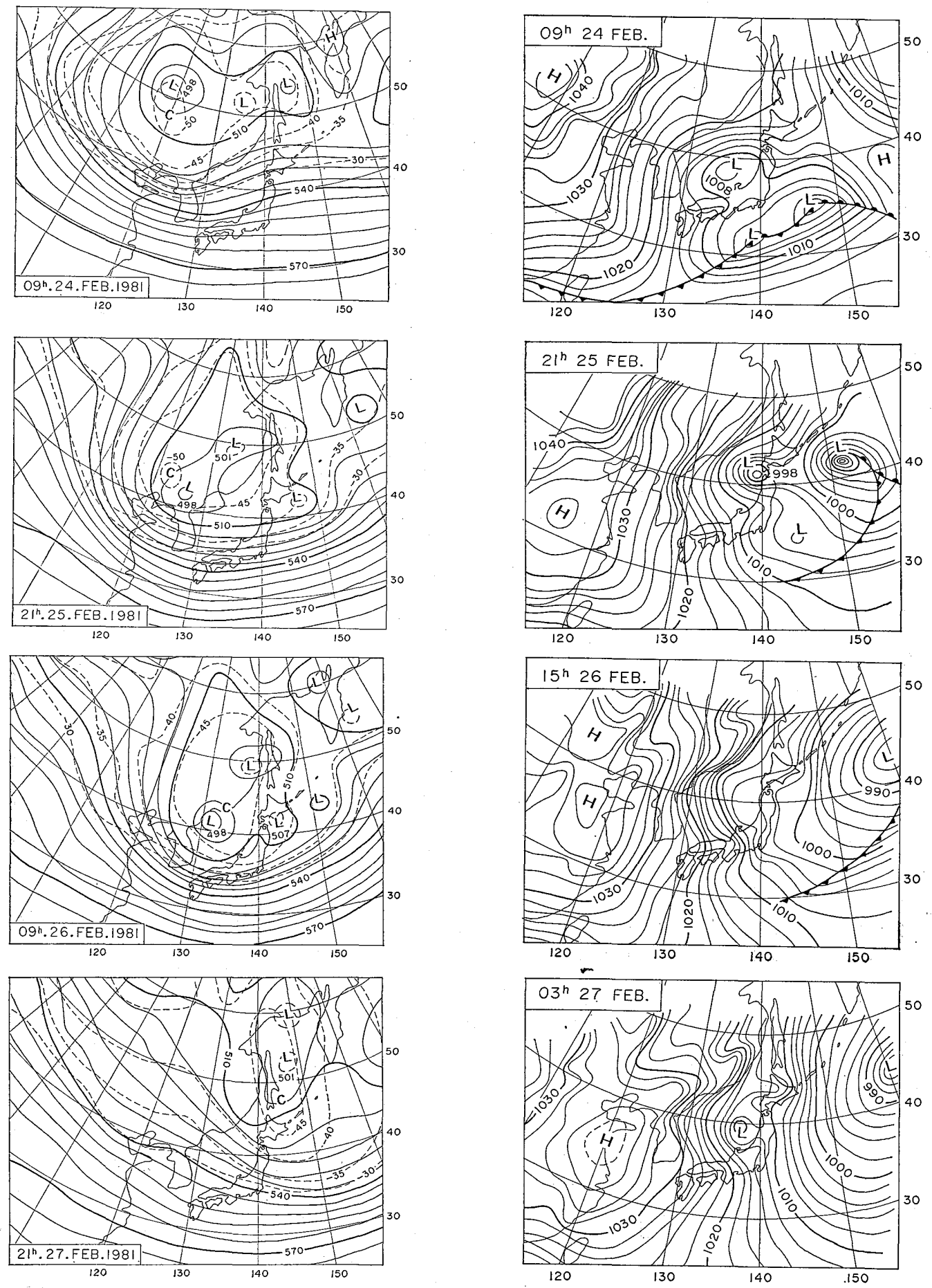

Fig. 1500 mb-maps. 24-27 Feb. 1981 (a) 09 JST 24 th. (b) 21 JST 25 th. (c) 09 JST 26 th. (d) 21 JST 27 th.

Fig. 2 Surface-maps. 24-27 Feb. 1981 (a) 09 JST 24 th. (b) 21 JST 25 th. (c) 15 JST 26 th. (d) 03. JST 27 th. 

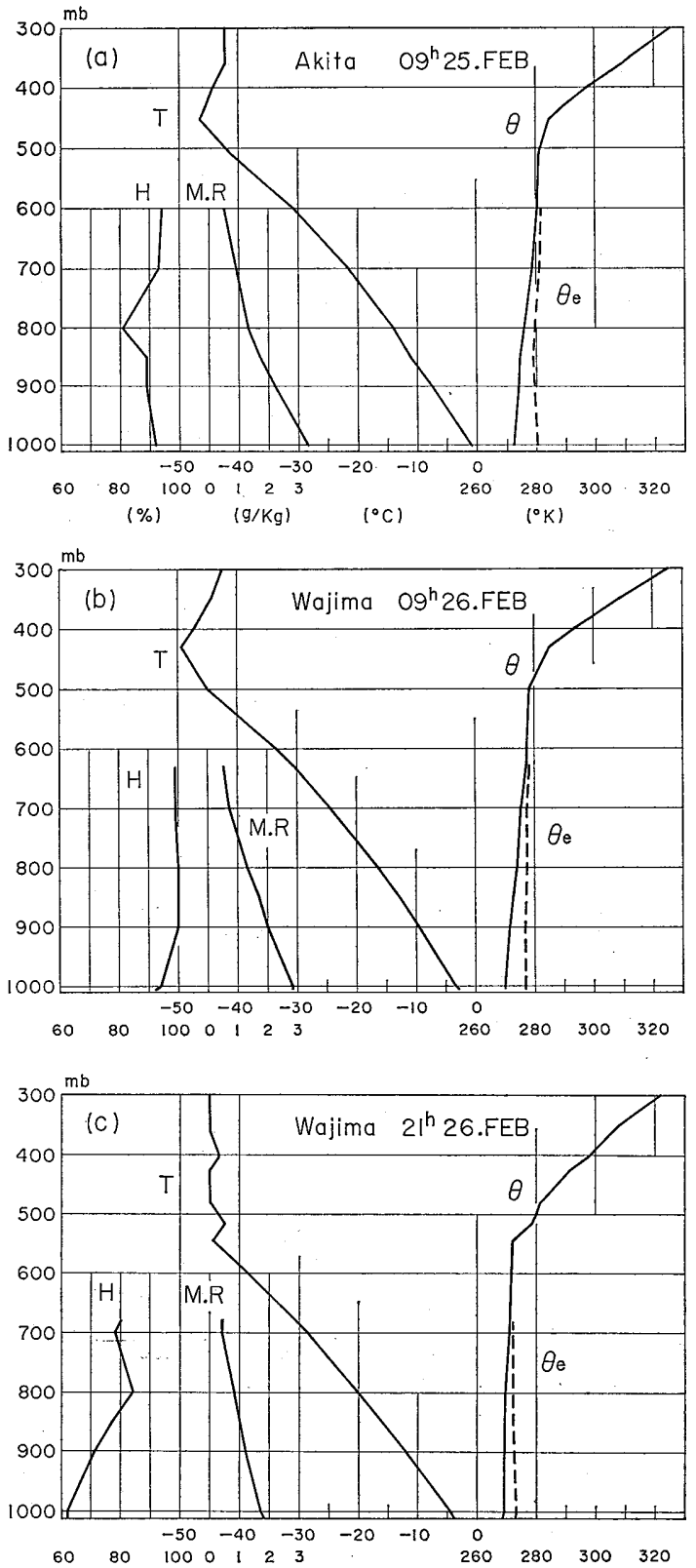

Fig. 3 Ascent curves of humidity, mixing ratio, temperature, potential temperature and equivalent potential temperature.

(a) 09 JST 25 th Feb. 1981, Akita

(b) 09 JST 26 th, Wajima

(c) 21 JST 26 th, Wajima
に，シベリヤ東部に中心を持っている大きな切離 低気圧が形成された。この低気圧は複数の中心を 持ち，東方へ移動した。その中のひとつの中心 は，26日09時には日本海に移動し，27日には衰光 てトラフとなり, 東方洋上へ移動した。も5 1 つ の中心は26日09時に樺太に達し，27日21時にはオ ホーツク海に移動した。

\subsection{2 下層の状態}

$500 \mathrm{mb}$ の切離低気圧の東側で，日本海に 2 個 の小低気圧が発生した。3 時間毎の極東天気図で 見ると, 第 1 番目の低気圧 (以後小低気圧 1 とよ ぶ) は，24日09時に日本海中部に閉じた形で解析 された(第 2 図 a)。雲系については後述するが, 衛星写真からは24日09時以前に低気圧が発生して いたかどらかの点は，上層雲が覆っていたために 確認できなかった。小低気圧 1 は24日21時には秋 田沖，25日21時には津軽海峡付近に進んで（第 2 図 b ），26日15時には消隇した（第 2 図 c )。第 2 番目の低気圧（同じく小低気圧 2 とよぶ）は, 26 日15時に日本海で等圧線が袋状になり（第 2 図 c），27日03時に日本海中部に低気圧として解析 された(第 2 図 d)。以後27日09時には新潟沖に進 み，27日15時には消滅して行った。小低気圧 2 に ついては，衛星写真を見る限りでは，26日15時に はコンマ型かあるいはスパイラル型に近い形の雲 系が, 能登半島の西方に確認できるので, 能登半 島の西方に低気压が存在していたと推測出来る。 資料不足で明らかではないが，この低気圧が低気 圧 2 になったと推定される。

\section{2 小低気圧の特質}

\section{2 .1 スケール}

第 2 図の地上天気図, 括よび第 4 図, 第 5 図の 雲写真に見られる通り, $1000 \mathrm{~km}$ 程度以下の大き さであり，スケールは小さい。

\subsection{2 対流的に中立な層の深さ}

第 3 図の 25 日09時の秋田, 26日09時物よび21時 の輪島の状態曲線に見られるように，小低気圧付 近では, 地表面から深さ $5 \mathrm{~km}$ 以上が対流的に汪 ぼ中立な層になっている。冬期の日本海沿岸にお ける対流的にほぼ中立な層の平均的深さが，地表 面から怙よそ $3 \mathrm{~km}$ 程度であることからみれば， 小低気圧付近ではかなり深くなっていることがわ 
(a)

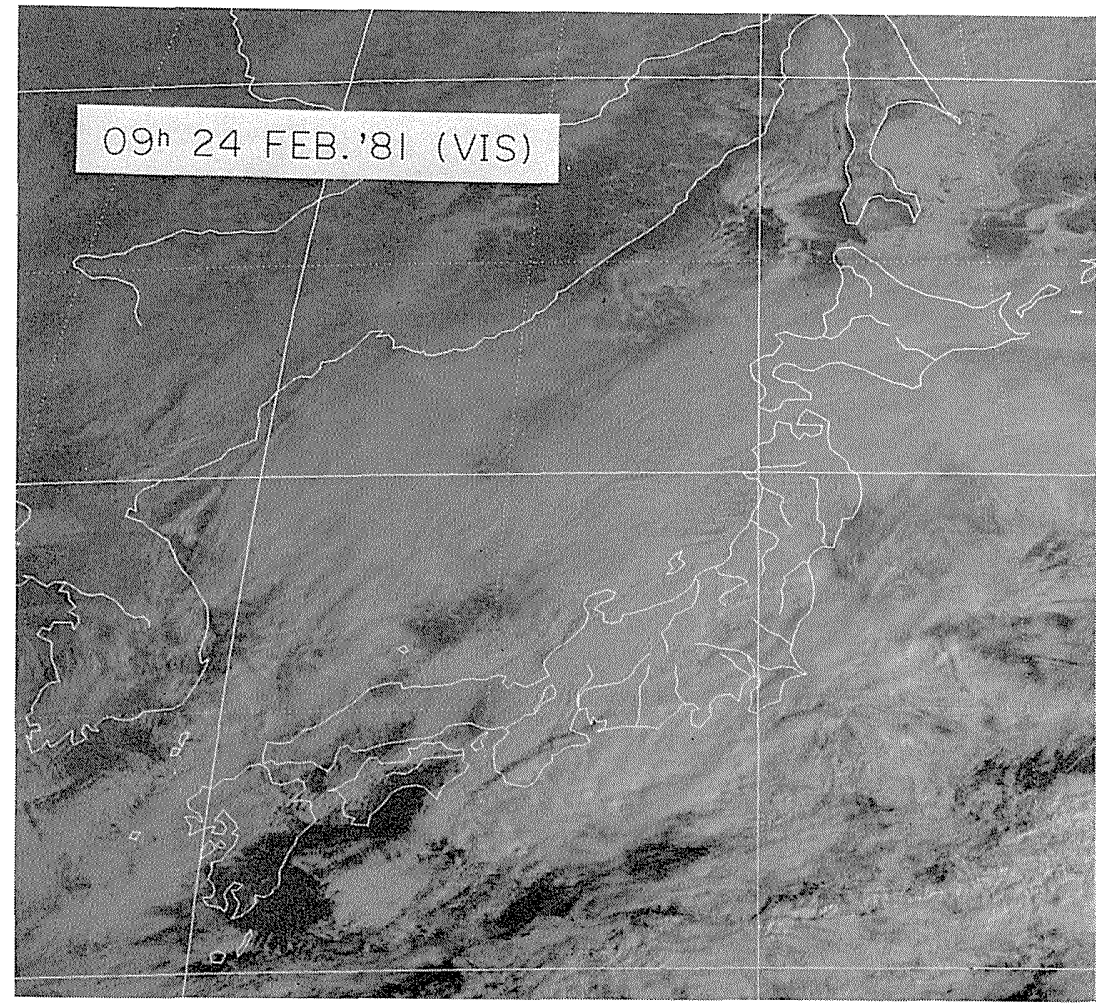

(b)

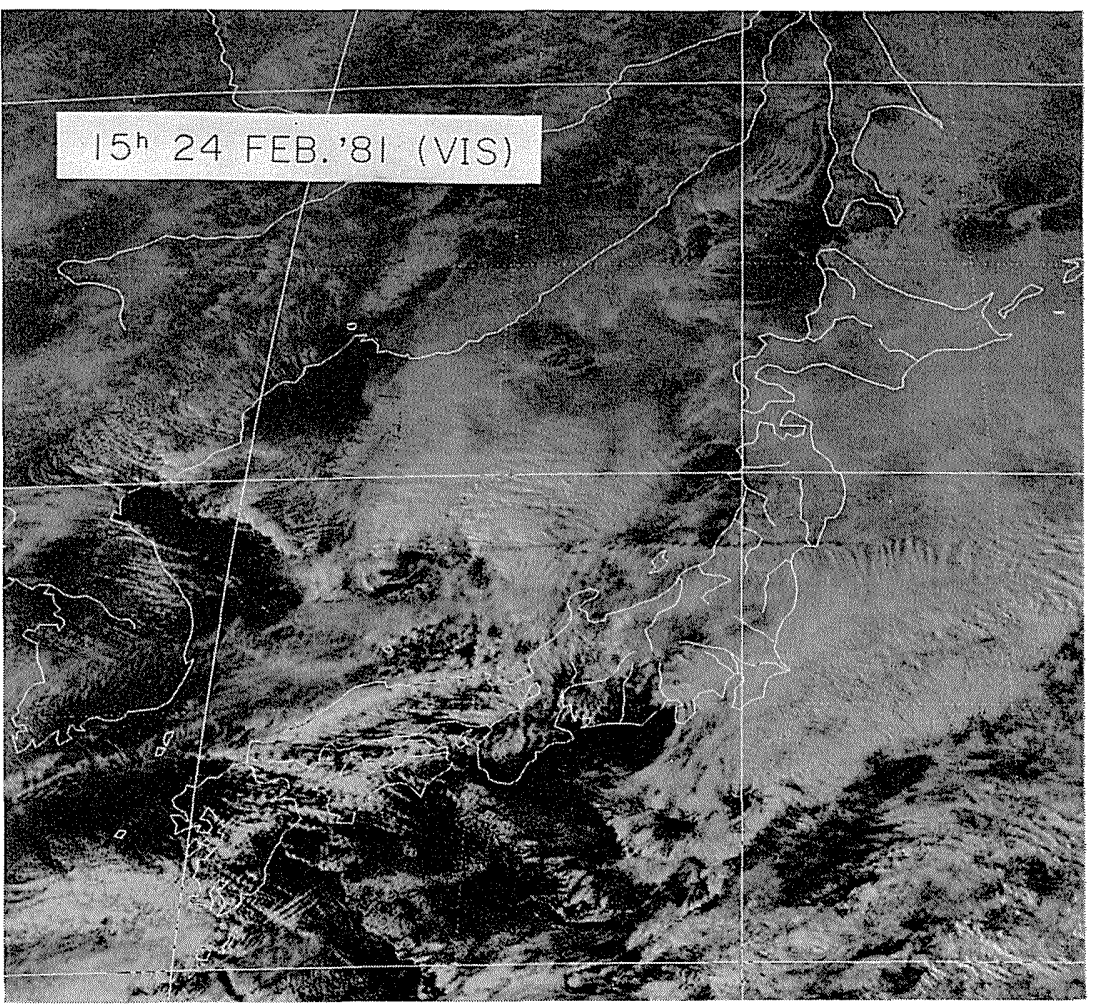




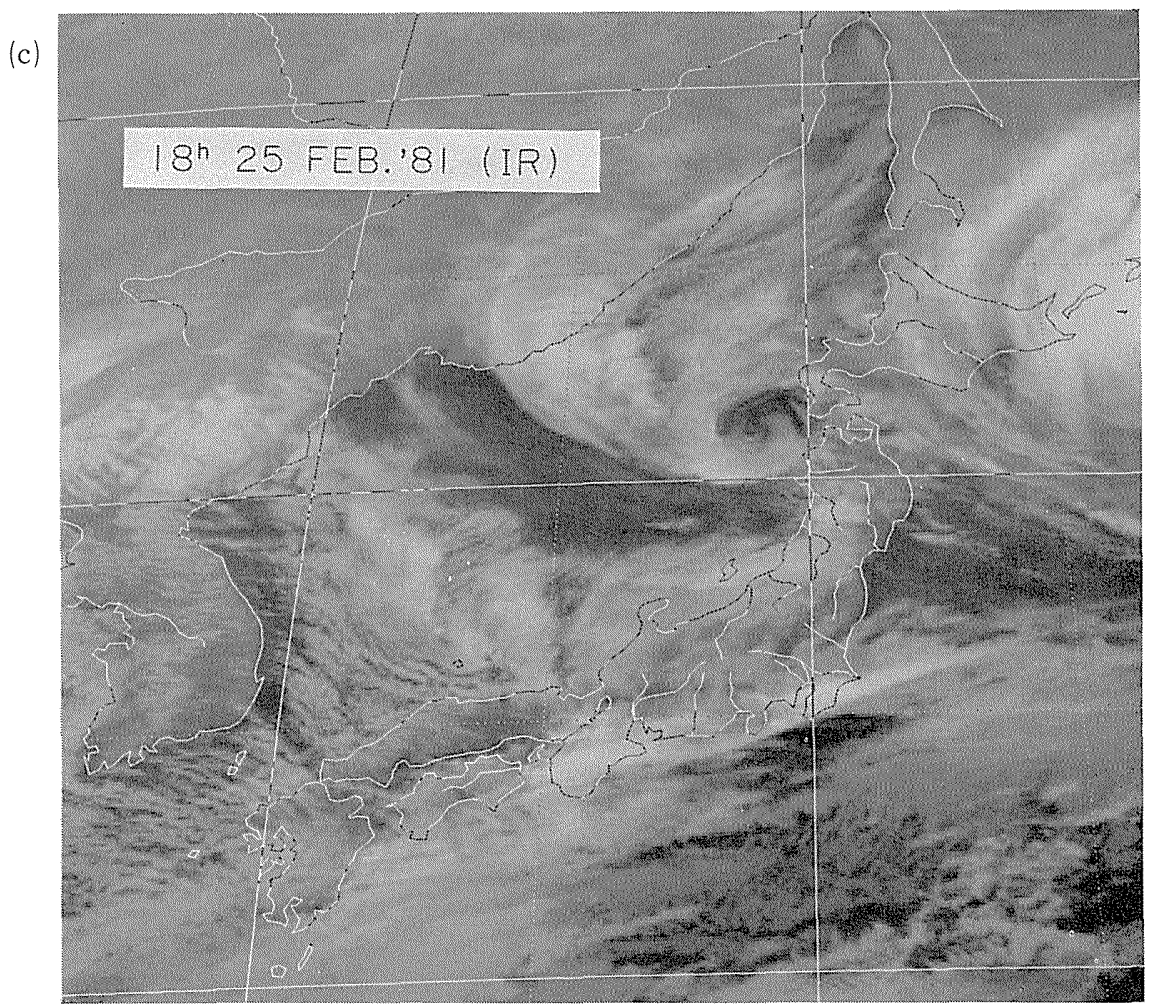

Fig. 4 Satellite cloud pictures. (GMS I)

(a) 09 JST 24 th. Feb. 1981 (VIS)

(b) 15 JST 24 th. (VIS)

(c) 18 JST 25 th. (IR)

かる。

\section{2 .3 雲系}

これらの小低気圧に伴なら雲は, 対流雲であ り，冬期にしては発達した積乱雲群を含んでい る。

第 4 図の衛星写真に見ら机るよらに，小低気圧 1に伴なら雲系は，24日09時には発達した積雲や 積乱雲の団塊で，発達積雲群であり，24日15時に はコンマ型になり，25日18時にはスパイラル型が 明瞭になっている。

小低気压 2 に伴なら雲系は, 26日03時では発達 積雲群であったが(第 5 図a), 上層の低気圧の 1 つが26日09時に日本海に移動したのに伴ない，26 日15侍にはコンマ型かあるいはスパイラル型に近 い形で雲系が確認され(第 5 図b)，27日01時には 明瞭なスパイラル型になった(第 5 図 c)。

いずれも発達積雲群からコンマ型に発達して,
最盛期にはスパイラル型になって衰えている。

ここで解析した 6 例では，上層の寒彾渦と直接 結びついている小低気圧は, 最盛期にはスパイラ ル型になっている。上層の弱いトラフに伴なって いるものは, 上記の小低気圧 1 だけが最盛期にス パイラル型になったが，他の例はコンマ型であっ た。Reedによれば，極気低気任は，初期には発 達積雲群であり, 最盛期にコンマ型を示すことが 報告されている。しかしながら，筆者らの解析で は極気低気圧でも，最盛期にはスパイラル型にな ることもあることを示していた。Anderson et al. によれば，上層の寒冷渦に伴なら雲系は，スパイ ラル型で特徴づけられることが記述されており, ここでの解析もこの特徵をよく示していた。

上層の切離低気圧に伴なって, 地上に気圧の谷 や低気圧が生ずることが知られている（Hsieh； 1948, Palmén；1951等)。一般には，この種の低 気圧は対流雲から成る雲系を持ち，前線性低気压 
(a)

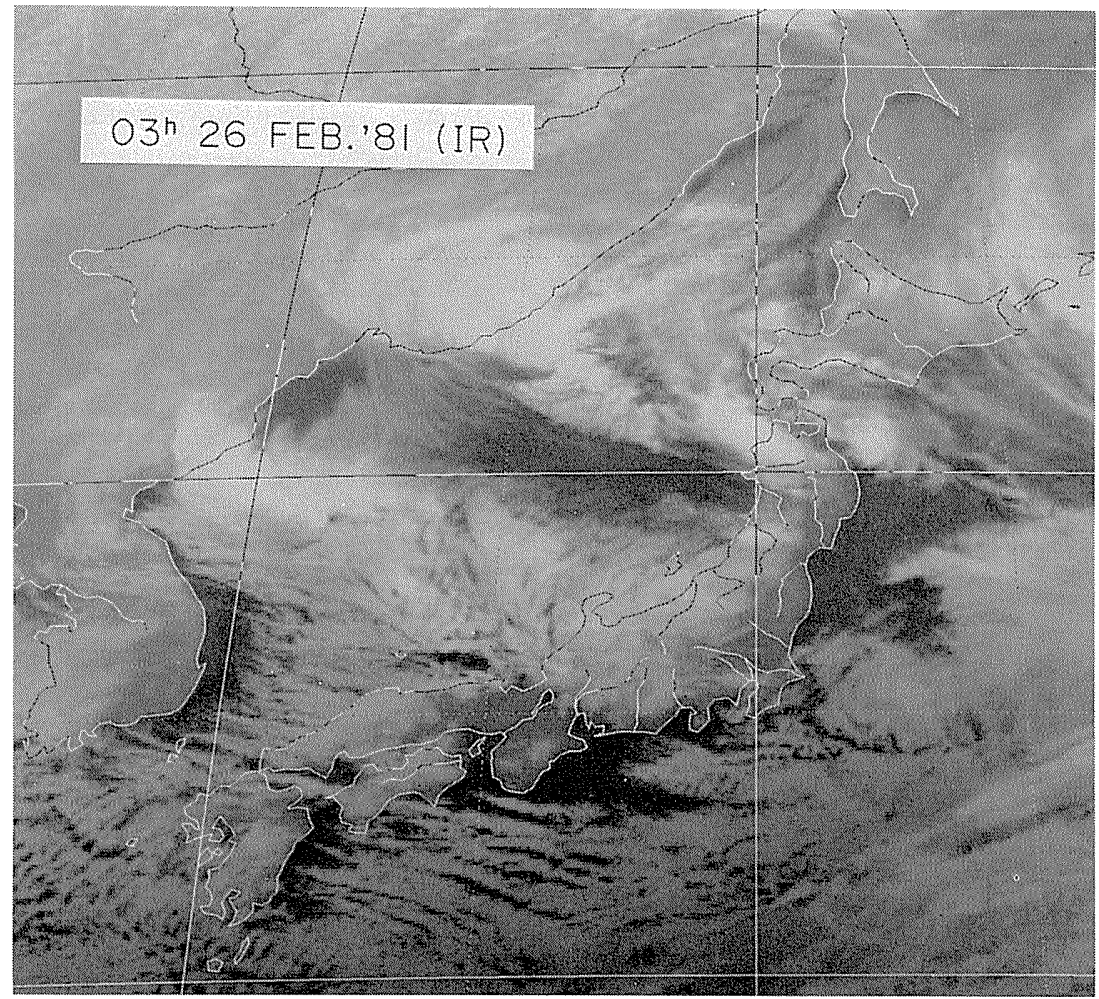

(b)

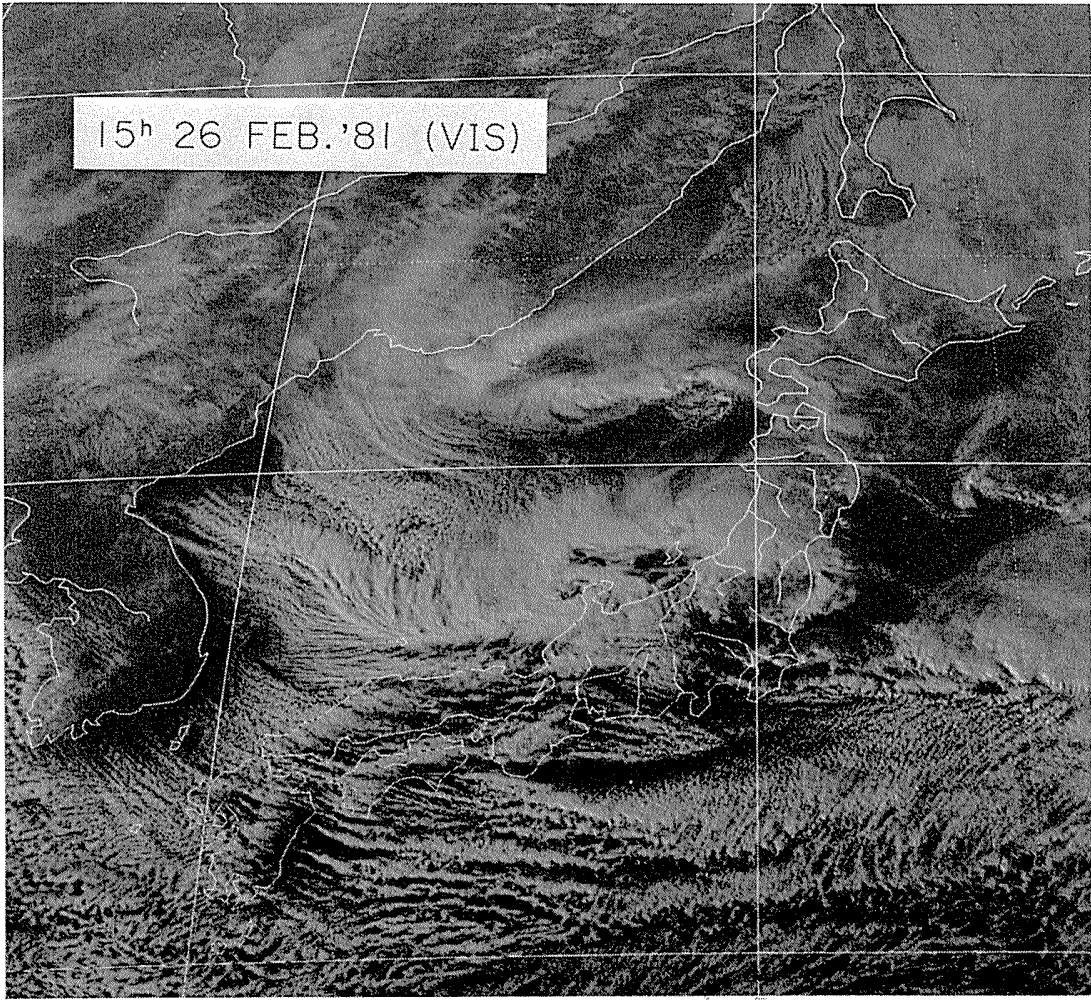


(c)

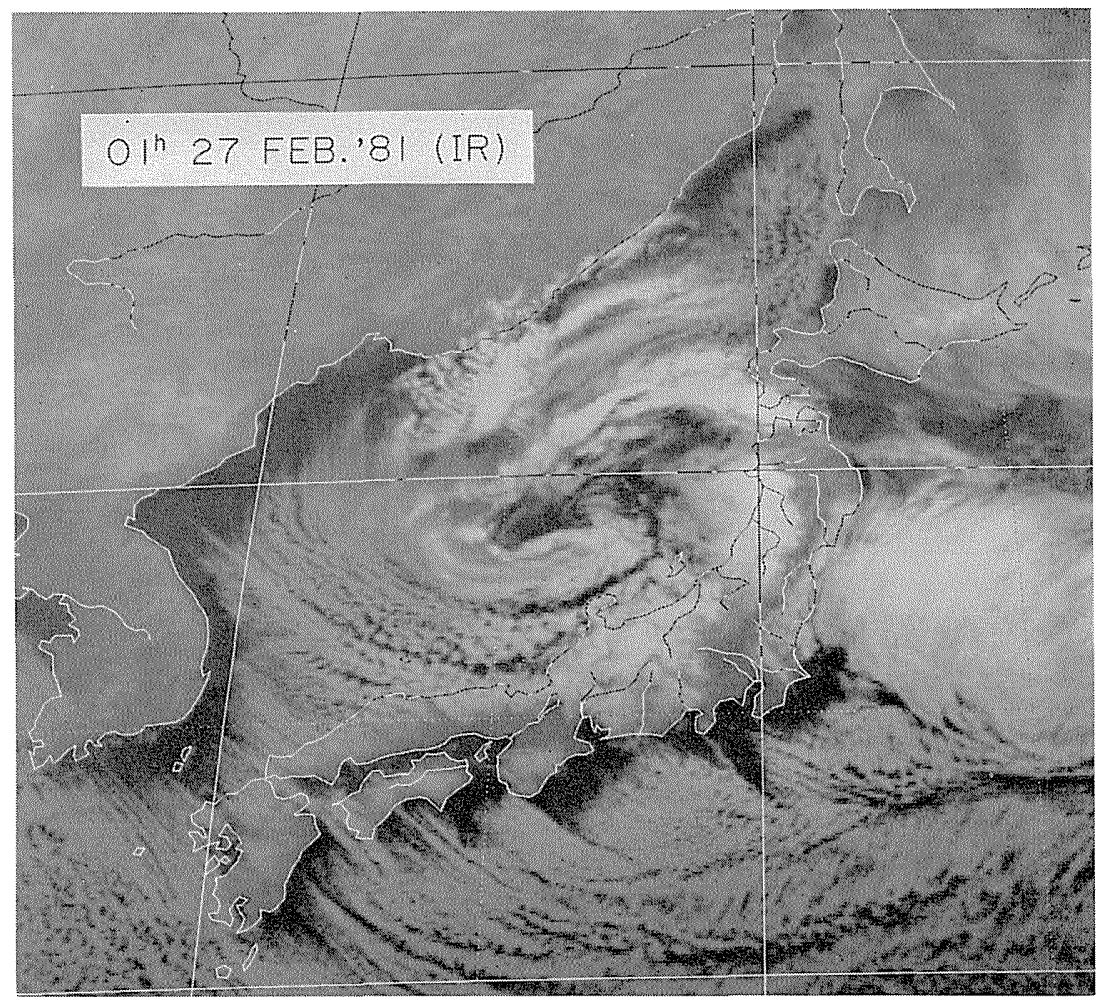

Fig. 5 Satellite cloud pictures. (GMS I)

(a) 03 JST 26 th. Feb. 1981 (IR)

(b) 15 JST 26 th. (VIS)

(c) 01 JST 27 th. (IR)

とは違って, 前線的な構造がないかあるは弱 く，極氛低気任とその性質がよく似ているが，最 盛期にはスケールが数千 $\mathrm{km}$ も市り，かつその瑟 系の形がよくスパイラル型に組織化されている点 が違っている。しかし，冬期の日本海では，この 種の低気压は $1000 \mathrm{~km}$ 程度以下とスケールが小 さく，また極気低気圧にもスパイラル型の雲系を 示すものもあることから，極気低気任と見なすこ とができる。

\section{$2.2 .4500 \mathrm{mb}$ の正渦度極大域との位置関係}

24日09時には，小低気压 1 は，500 mb のジェ ット気流の北側の正渦度領域の，弱いトラフに女 った正渦度極大の前面に位置していた（第 6 戍 a ）。小低気生 2 は，上層の切離低気玨のひとつ の中心にあった正渦度の極大の前面で発生してい る(第 6 図 b)。この低気王は，26日21時には， $500 \mathrm{mb}$ の低気压と位置が重なって，雲系はスパ
イラル型になっている。このような状態のときに は，上厤の切離低気王を構成している寒気団の南 部が占める面積の縮小，および切離低気圧南部の 低気圷中心の害弱にともなわれている(第7四)。 この状態は閉塞低気压の構造に類似している。し かし，これらの低気生は前線的な構造が明瞭では ないので，前線性低気王の閉塞現象とは違ってい る。 Palmén や Hsieh の解析によって知られて いる即時閉塞（Instant Occlusion）とよばれてい る現象に類似している。Palmén 等の場合には, 南の方に前線波動があって，それも含めて，外見 上前線性低気王の閉塞状態と同じに見える。ここ での例では，そのような南側の前線波動との結び つきが見られていない点では違っている。小低気 圧1の場合は，上層の弱いトラフによる正渦度極 大域之，地上の低気圧中心が，25日09時にはほぼ 同位㗨に重なって，雲系がスパイラル型になって いる。 


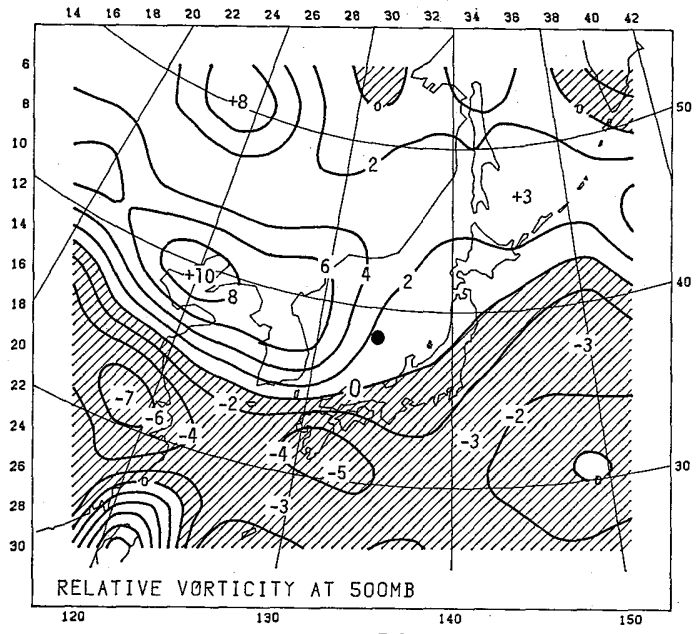

UNIT $=(10 * *-5 /$ SEC $)$
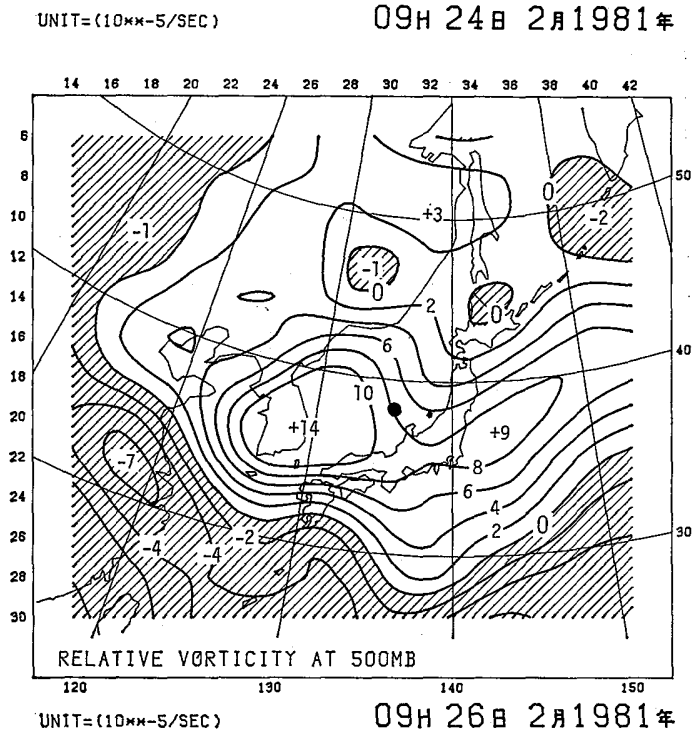

Fig. 6 The distributions of relative vorticity at $500 \mathrm{mb}$.

(a) 09 JST 24 the Feb. 1981

(b) 09 JST 26 th.

上層の正渦度極大の前面で小低気圧は発生し, 上層と下層の正渦度極大がほぼ垂直に重なって最 盛期を迎えていることが見られる。

\section{2 .5 その他}

以上の他に，次のような特徵が見られた。

(1) 同一の寒気団内にあって，低気圧に伴なら 前線系は明膫ではない。

(2) ジェット気流の北側の対流圏内の偏西風带 の深い層にわたる傾圧場の中に存在している（第

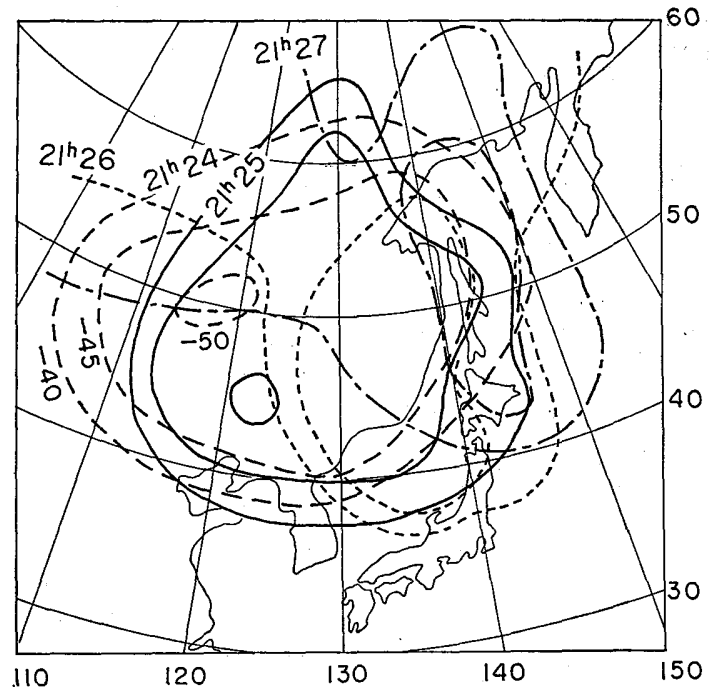

Fig. 7 The changes of isotherms of $-40^{\circ} \mathrm{C}$ and $-45^{\circ} \mathrm{C}$. (21 JST 24 th. -21 JST 27 th Feb. 1981)

1 図)。

Reed によれば，極気低気圧とは，前線性低気 圧と違って，次のような特質を備光た低気圧であ る。

（i）主要前線带の極側の全く寒気団の中にあ って，前線的な構造が見られない。

(ii) スケールが $1000 \mathrm{~km}$ 程度以下と小さい。

(iii) 対流圈の相当な深さを通じて 条件附不安 定層である。

（iv）対流活動が活発である。

（v）冬期の海洋上で最も頻度が多く，低層で 海面から顕熱の補給を受けている地域に発生して いる。

（vi） ジェット気流の極側の強い低気圧性の水 平の風のシァーが著しく，対流圈を通じて傾圧性 が存在している領域に存在している。

(vii) 最盛期には，コンマ型の対流雲群の型を もち, 地上の低気圧の中心は, コンマの頭の付根 に位置している。

これらの特徴に照合してみれば，これまで記述 して来たよらな2つの小低気圧は, 極気低気圧で あることを示している。最盛期には雲系がスパイ ラル型になっている点だけが Reed の記述と違っ ているが，発達過程ではコンマ型を経過してお り,また対流雲で構成されている点は同じであ る。むしろ, “極気低気圧に伴なら雲系は, 最盛 
期には, コンマ型もしくは，スパイラル型にな る”と記述した方が妥当であると思われる。

\section{3. 安定度解析}

これらの小低気圧の特質である深い刘流的に中 立な層の形成を調べるために, 安定度変化率の分 布を調べた。

通常の季節風の吹き出しの場合には, 地面から ほぼ $3 \mathrm{~km}$ 程度の深さの対流的にほぼ中立に近い 層が存在しているのに比べて，この場合の小低気
压近辺では，地面から 5 6 $\mathrm{km}$ 程度とかなり厚 い層を形成している。衛星写真の雲解析図から， 雲頂高度もこの程度の高さに及んでいることが見 られる。

$3 \mathrm{~km}$ 程度までの下層の対流的に中立な層は, 主として海面からの加熱によって形成されている と考えられるので，ここでは $3 \mathrm{~km}$ 以上の層の 安定度の変化率を問題にする。

乾燥断熱変化を仮定すると, 安定度の変化率は 次式で示される。

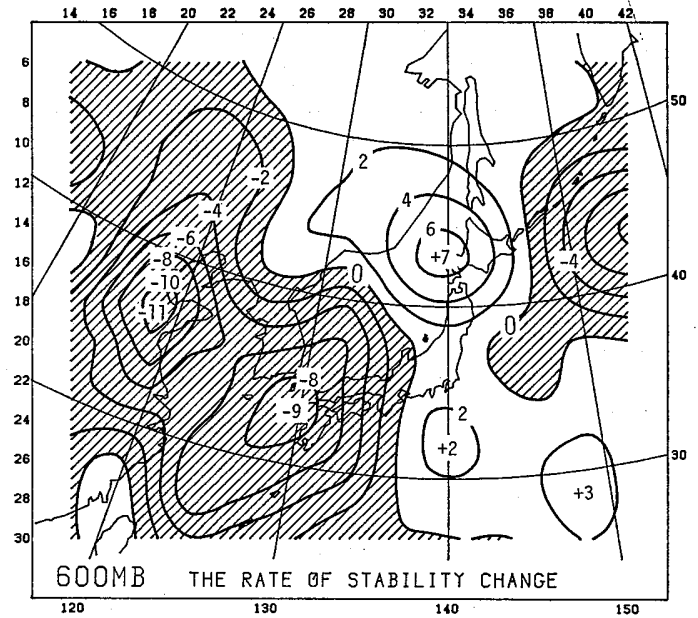

UNIT $=(10 * K-7$ C/MB.SEC $) \quad 09 H 24$ 日 2月1981年

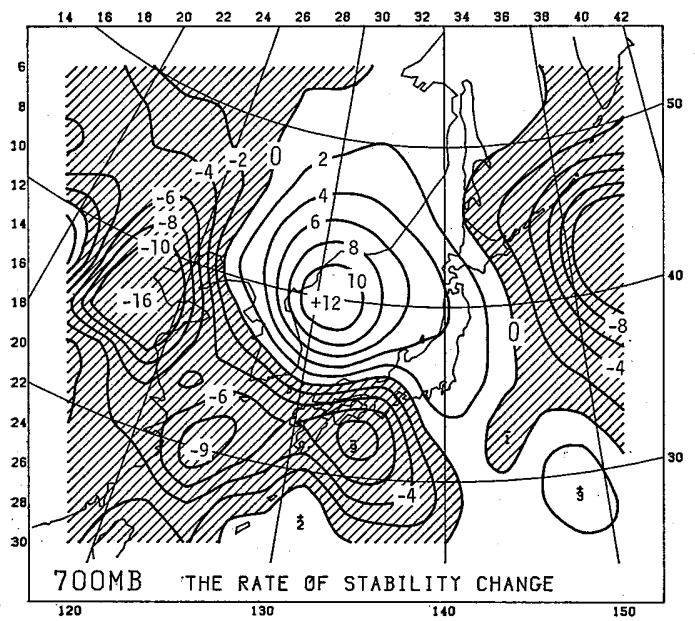

UNIT $=(10 \times \times-7$ C/MB.SEC $)$

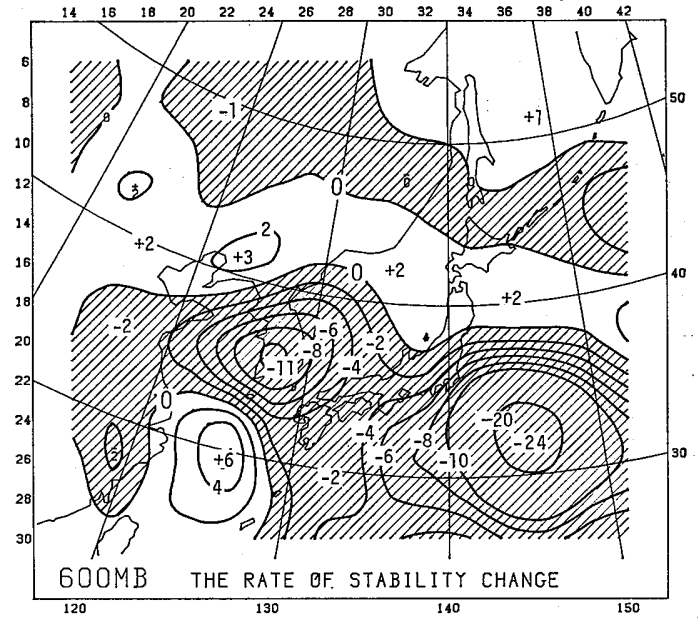

UNIT $=(10$ Nx-7 C/MB.SEC $) \quad 09 H 26$ 日 2月1981年

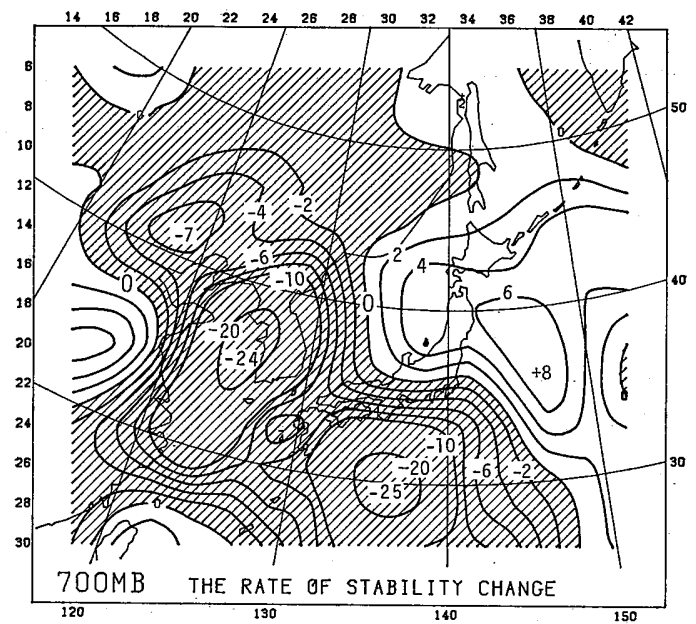

UNIT $=(10 \times k-7$ C/MB.SEC $) \quad 09 H 26$ 日 2月1981年

Fig. 8 The estimated rate of stability change at 600 and $700 \mathrm{mb} .\left(\times 10^{-7} \mathrm{C} \mathrm{mb}^{-1} \cdot \mathrm{sec}^{-1}\right)$

(a) 09 JST 24 th Feb. 1981.

(b) 09 JST 25 th. 


$$
\begin{aligned}
\frac{\partial}{\partial t}\left(\frac{\partial \theta}{\partial p}\right)= & -\frac{\partial}{\partial p}\left(u \frac{\partial \theta}{\partial x}+v \frac{\partial \theta}{\partial y}\right) \\
& -\frac{\partial \omega}{\partial p} \frac{\partial \theta}{\partial p}-\omega \frac{\partial^{2} \theta}{\partial p^{2}}
\end{aligned}
$$

気象庁電計室の 6 層ファインメッシュプリミテ イブモデル（以下 $6 \mathrm{~L}-\mathrm{FLM}$ とよぶ）の初期解析 值を用いて，(1)の右这の量を600，700，800，900 $\mathrm{mb}$ の各面で計算した。このモデルの初期解析値 の $u, v, \omega$ は, 大規模場に対する近似值であり, 特に垂直気流 $\omega$ は，加熱項を無視した準地衡風近 似の $\omega$ 一方程式の解である。

その結果,

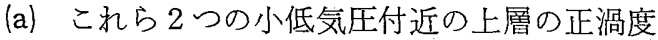
極大域の前面では，下層から $600 \mathrm{mb}$ 高度まで安 定度変化率は正で, $10^{-6 \circ} \mathrm{C} /(\mathrm{mb} . \mathrm{sec})$ のオーダー にもなり，これは 12 時間当り $0.6^{\circ} \mathrm{C} / 100 \mathrm{~m}$ の安 定度の悪化に相当する（第 8 図 $\mathrm{a}, \mathrm{b}$ )。(1)式のな かで最も卓越していたのは, 右边第 2 項であり, こ水は水平発散による項である。安定度の悪化域 では, 収束場が地表面から $600 \mathrm{mb}$ 以上にもおよ び，特に対流圈中層の安定度を悪化させているこ

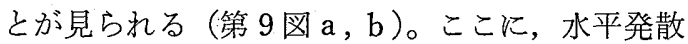
は一 $\frac{\partial \omega}{\partial p}$ を意味している。

(b) ウラジオストックの状態曲線の図は省略し たが，大陸上では， $900 \mathrm{mb}$ 付近以下の対流圈下 層の安定度は著しく良く, $700 \mathrm{mb}$ 程度以下では 対流的に安定であった。それが，本邦の日本海沿 岸では, 第 3 図の輪島の状態曲線に見られるよう に, $700 \mathrm{mb}$ 程度以下の下層も刘流的に注涪中立 な成層に変っている。これは，日本海上での顕熱 及び水蒸気の補給によるものであることはよく知 られている。上層の正渦度域の前面では, 対流圈 中層では(a)に述べたように, 水平発散効果によっ て安定度が悪化して扮り，地表面から $500 \mathrm{mb}$ に まで特よぶ対流的に活ぼ中立な，安定度が良くな い深い層が形成されていることが示されている。

(c) 正洞度極大域の後面では，対流圈中層の 700 500 mb の間の層で，安定度变化率は負で あって，安定度が良くなっていることがわかる (第 8 図)。従って，日本海上での対流的にほぼ中 立な層の高さは，この領域では，地表面から700 $\mathrm{mb}$ 程度以下の層に限られて, 低くなっている。 上層に寒気団があって，その領域全体が安定度が 悪くなるという説明がよくなされているが，そう
ではないことを示している。

\section{4. 小低気圧の形成}

すでに述べたように，ここで解析した小低気庄 は, 上層の正渦度の極大の前面で, 上層に正渦度 移流があるよらな領域で発生，発達している。

地上に括沙度変化率を, 上層の渦度变化率 と関連させて調べるために，次のような層厚の渦 度方程式を用いた。この式は, Petterssen（1956） によれば発達式と名付けられているものである。 準地衡風近似を用い, 地衡風渦度や地衡風には添 字 $g$ をつけて示した。

$$
\begin{aligned}
\frac{\partial \zeta_{g 0}}{\partial t}= & -\mathrm{V}_{g u} \cdot \nabla\left(\zeta_{g u}+f\right)+f\left(\frac{\partial \omega}{\partial p}\right)_{u} \\
& +\frac{1}{f} \nabla^{2} \int_{P o}^{P u} \mathrm{~V}_{g} \cdot \nabla\left(\frac{\partial \Phi}{\partial p}\right) d p \\
& -\frac{1}{f} \nabla^{2} \int_{P o}^{p u} \frac{\alpha \omega}{\theta} \frac{\partial \theta}{\partial p} d p \\
& -\frac{1}{f} \nabla^{2} \int_{P_{0}}^{P u} \frac{R}{C_{P} P} \frac{d Q}{d t} d p
\end{aligned}
$$

ここに，添字 0 は地表面の量， $u$ は $500 \mathrm{mb}$ の 量を示している。外部から単位時間に与えられた 熱量 $\frac{d Q}{d t}$ は次の式によって評価した。

$$
\frac{d Q}{d t}=\frac{C_{P} T}{\theta}\left(\frac{d \theta}{d t}\right)
$$

(2)式和よび(3)式の右辺の量を同じく12時間の時 間間隔の電計室の $6 \mathrm{~L}-\mathrm{FLM}$ の初期解析値を用い て，極東領域について計算した。(3)式の右辺の $\frac{d \theta}{d t}$ は, $\left(-\frac{\partial \theta}{\partial t}+\mathrm{V} \cdot \nabla \theta+\omega \frac{\partial \theta}{\partial p}\right)$ を計算しでち た。 $\frac{\partial \theta}{\partial t}$ は12時間間隔の中央差分で与えた。

(a) 第10図に見られるように，(2)拉よび(3)式の 右辺の量から計算した地表面の渦度変化率の分布 をみると，正渦度の著しい増大域は，小低気压の 形成域とよく一致している。

(b) (2)式の右辺各項の大きさを調べてみると; 小低気圷形成域での正渦度の増大に対しては，第 1 項の上層の渦度移流項と, 第 5 項の非断熱加熱 項の正の寄与が最も大きかった（第11,12図)。

(c) (2)式の第 1 項と第 3 項を合わ吼を風のシ ァーが高さと共に方向が変らない簡単な傾圧大気 では, Sutcliffe の発達項, $-\mathrm{V}_{g}{ }^{\prime} \nabla\left(\zeta_{g}{ }^{\prime}+2 \zeta_{g 0}+f\right)$ になることが証明される。 

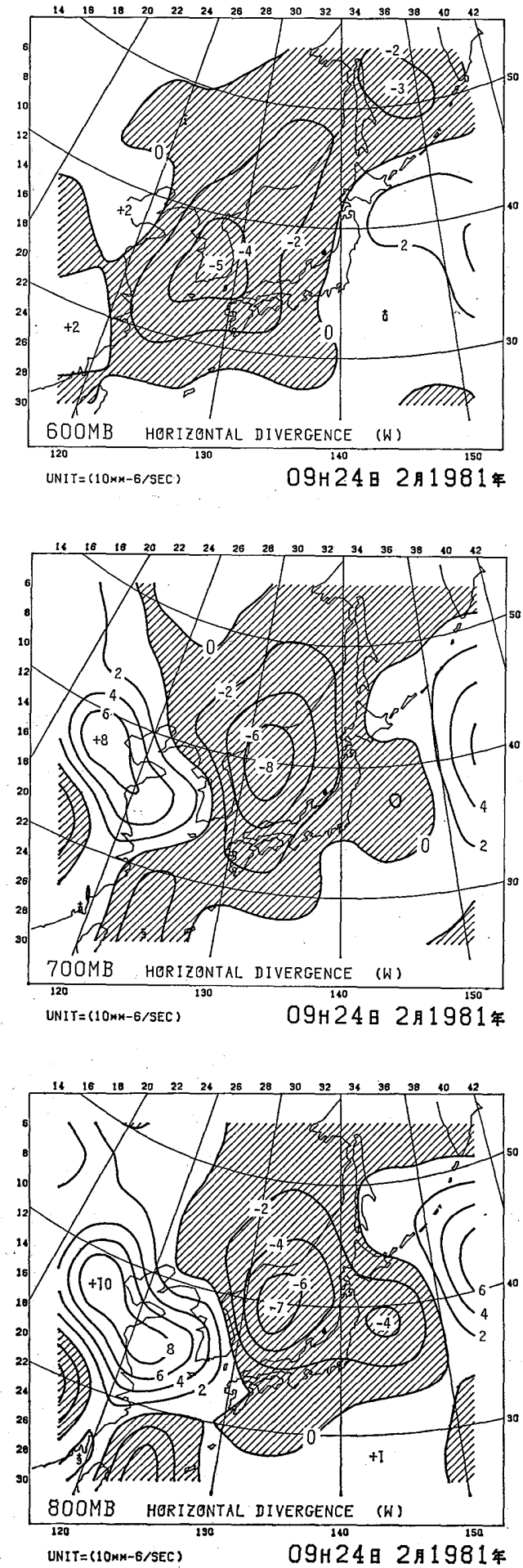
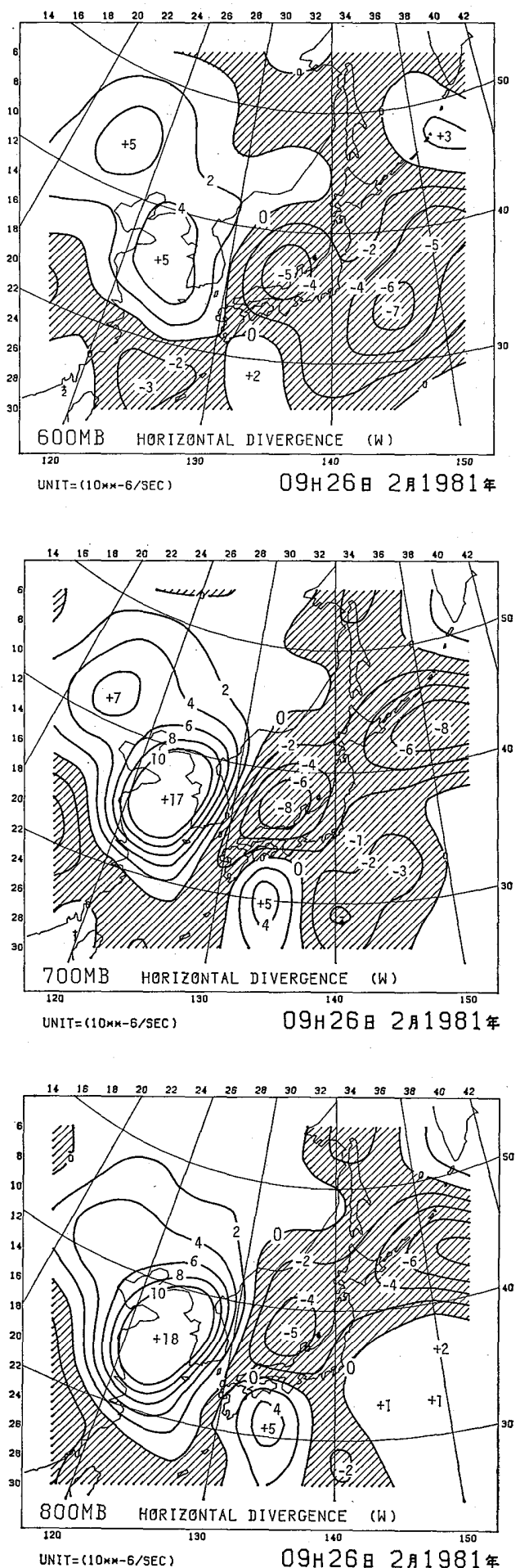

Fig. 9 The distributions of horizontal divergence at 600,700 and $800 \mathrm{mb} .\left(\times 10^{-6} \mathrm{sec}^{-1}\right)$ The date of (a) and (b) are the same as in Fig. 8. 

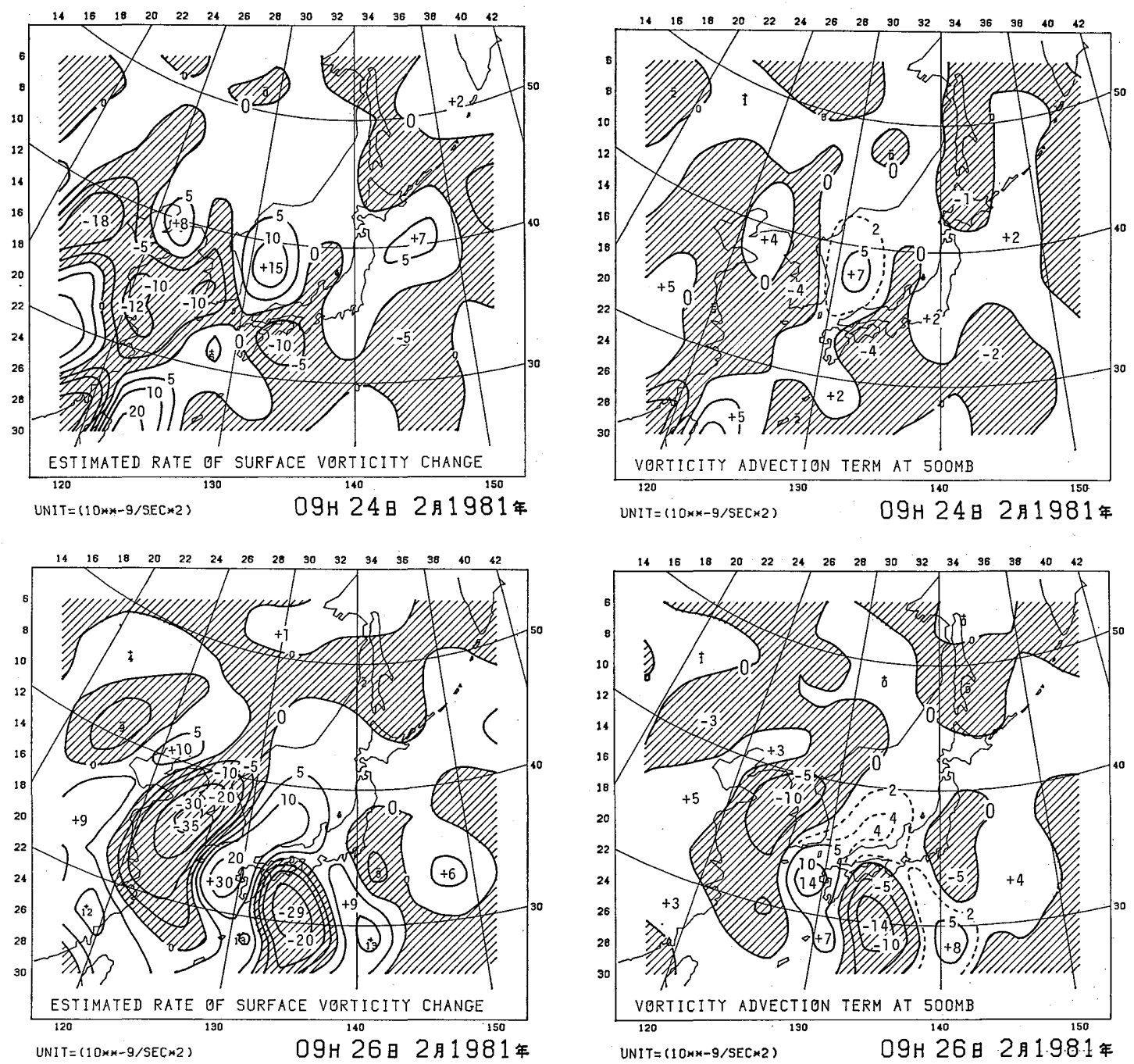

Fig. 10 The distributions of estimated rate of surface vorticity change. $\left(\times 10^{-9} \mathrm{sec}^{-2}\right)$

(a) 09 JST 24 th Feb. 1981.

(b) 09 JST 26 th.

ここに, $\mathrm{V}_{g}^{\prime}$ は $1000 \mathrm{mb} 500 \mathrm{mb}$ の間の 地衡風の差であり， こ美は同じく地衡風渦度の差 である。それを入れると(2)式は，

$$
\begin{aligned}
\frac{\partial \zeta_{g 0}}{\partial t}= & -\mathrm{V}_{g} \nabla\left(\zeta_{g}^{\prime}+2 \zeta_{g 0}+f\right) \\
& -\mathrm{V}_{g 0} \cdot \nabla\left(\zeta_{g 0}+f\right)+f\left(\frac{\partial \omega}{\partial p}\right)_{u} \\
& -\frac{1}{f} \nabla^{2} \int_{P_{0}}^{P u} \frac{\alpha \omega}{\theta} \frac{\partial \theta}{\partial p} d p
\end{aligned}
$$

Fig. 11 The distributions of values of vorticity advection term at $500 \mathrm{mb}$.

The date of (a) and (b) are the same as in Fig. 10.

$$
-\frac{1}{f} \nabla^{2} \int_{P o}^{P u} \frac{R}{C_{P} P} \frac{d Q}{d t} d P
$$

となる。即ち，近似的に上層の渦度移流効果の 地表面発達に対する寄与は, Sutclitte の発達項 に含まれている。この項は, 順圧大気では上層の 渦度䔟流は地表面発達に対しては寄与せず，傾圧 性が大きい大気では大きな寄与をしていることを 示している。この解析では, 上層の渦度移流項, 従って Sutclitte の発達項が小低気圧の低気圧形 


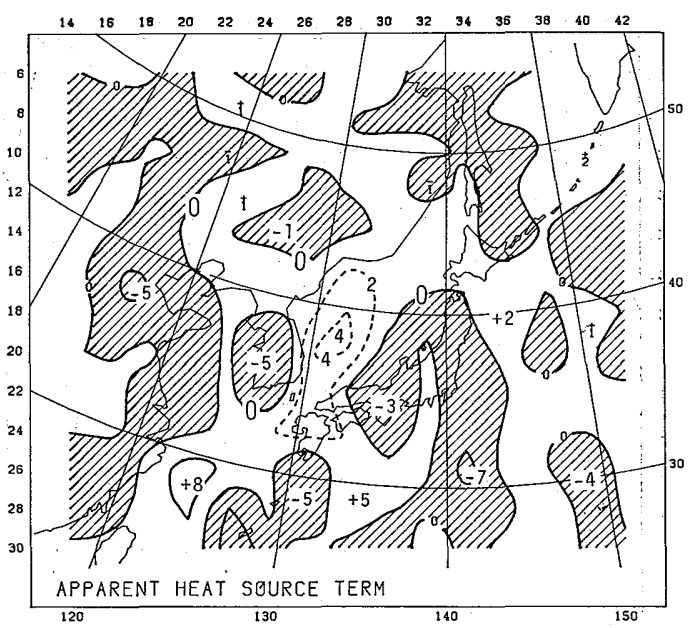

UNI T $=(10 * *-9 / \mathrm{SEC} \times 2)$

O9H 24日 2月1981年

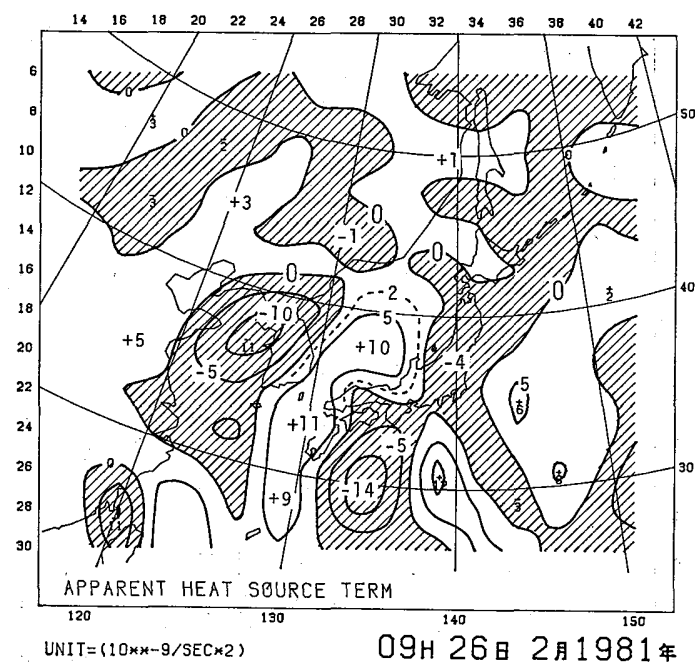

Fig. 12 The distributions of values of apparent heat source term.

The date of (a) and (b) are the same as in Fig. 10.

成に対して大きな寄与をしていることが見られ， 傾圧性が低気圧形成に対して重要であったことを 示している。

(d) 次に Richardson 数

$$
R i=-\frac{\alpha \cdot \partial \theta}{\theta} \cdot\left[\left(\frac{\partial u}{\partial p}\right)^{2}+\left(\frac{\partial v}{\partial p}\right)^{2}\right]
$$

を, 同じ 6L-FLM の初期值資料を用いて, 各 面で計算して，その分布を求めた。第13，14図に 示すように，小低気圧 1 拈よび 2 の発生, 発達域 は, 10以下といら小さい Richardson 数の地域で
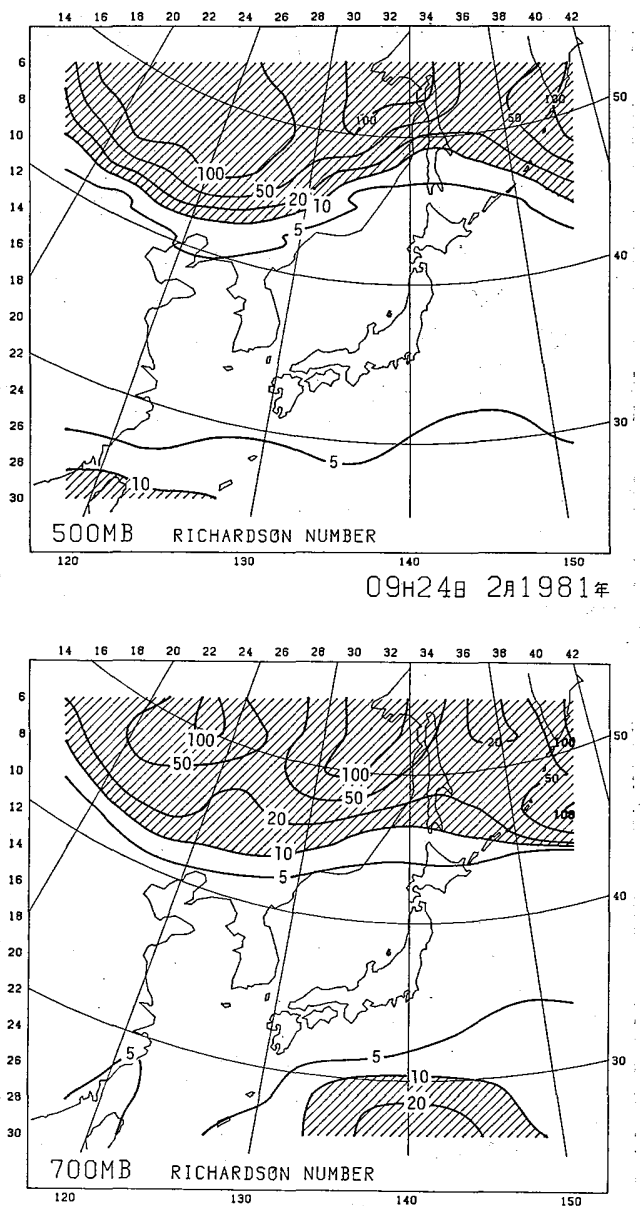

09н24日 2月1981年

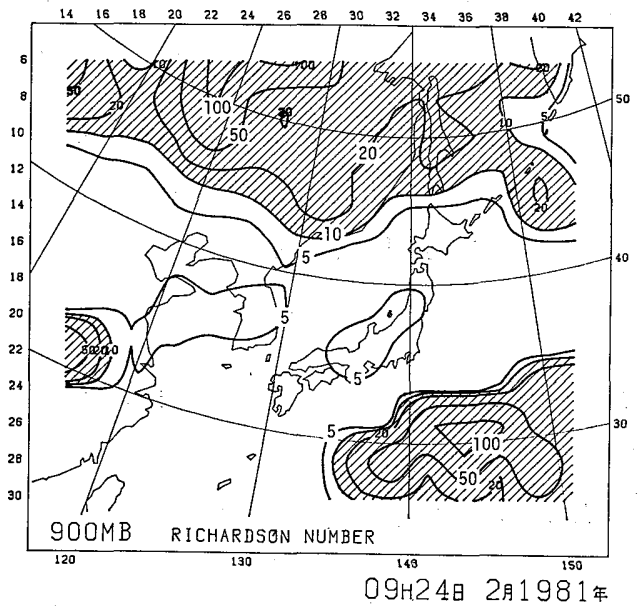

Fig. 13 The distributions of Richardson numbers at 500,700 and $900 \mathrm{mb}$. 09 JST 24 th Feb. 1981. 

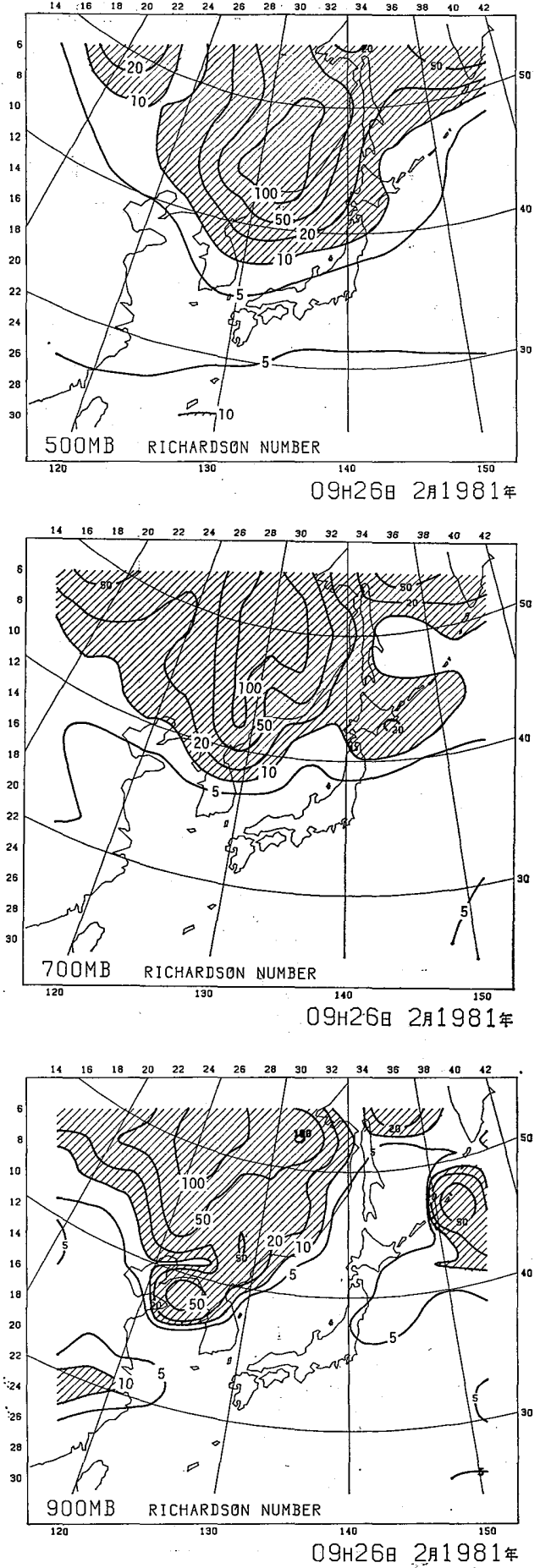

Fig. 14 Same as Fig. 13, but the date is 09 JST 26 th.
あったことが判る。

(e) 極気低気圧はスケールが $1000 \mathrm{~km}$ 程度以 下と小さいことを解析でも明らかにしてきた。こ のような小さいスケールの低気圧は, 通常の条件 では，傾圧不安定理論では期待されない。このよ らなスケールの不安定波動が存在する条件につい てミ1. で述べたよらに種々な議論が行われて来 た。

ここでの解析結果では,

i ) Richardson 数が10以下と非常に小さい領 域で発生発達していること。

ii) Sutclitte の発達項の大きい領域, 即ち傾圧 性の大きい領域で発生, 発達していること (第11図)。

iii）非断熱加熱項 (Apparent heat source term) が大きい領域で発生, 発達していること（第 12図)。日本海一面や太平洋一面というよう な海面からの顕熱輸送の大きい領域といらこ とではなく，この項は積雲対流活動の旺盛な 領域で大きくなっていることから, 積雲対流 活動による凝結の潜熱の放出が大きな寄与を していると推定されること。

が示された。このことは，これらの小低気圧の小 さなスケールは，岸保（1970・a・b）及び時岡 （1973）の理論一大規模の一般流が傾圧性を持ち, 積雲対流活動による凝結の潜熱の放出が大きいと き, Richardson 数が10程度以下と小さい場では, $1000 \mathrm{~km}$ 程度の小さいスケールの擾乱が不安定 になり得ること一によって説明され得ることを示 唆している。

即ち, Rasmussen や $\Phi k l$ land が議論した第 2 種条件付不安定効果之, Duncan による深い傾圧 場でしかも静的安定度が覀い気勫であること，の 双方の不安定効果が協同して，1000 km 程度の 小さいスケールの低気圧が形成されることを示唆 している。

\section{5. 切離低気压, 極気低気圧と平野部豪雪}

上層の寒泠渦, 即ち上層の切離低気珐が, シベ リヤから南下して日本海に入ると, 日本海沿岸地 方で里雪型或いは平野部豪雪を生ずることはよく 知られている (Matsumoto et al., 1965; 福田, $1968 \cdot a$; 宮沢，1968等)。これらの寒冷渦は同 時に低温の中心を持っており，また正渦度の極大 
であある。従って，日本海の上層の低温と正渦度 の極大の存在は, 平野部豪雪の予報の指標として 広く使われている(倉嶋，1968）。そのようなとき には，地表面では袋型低圧部とよばれている気圧 の谷になり，しばしば小低気圧が存在している。 福田 (1968・b) は, ジェット気流の北側の著しい 正渦度領域で，小低気圧が到達したときに平野部 豪雪を生ずることを強調している。

しかしながら，これらの小低気圧の性格や構 造，さらに平野部豪雪に果たす役割については明
らかではなかった。気象衛星資料が得られるよう になってからは，日本海に背の高い積乱雲群がし ばしば存在し，時にはコンマ型やスパイラル型等 の組織的な雲系に発達することが見られるように なった。

また，大雪をもたらすような発達した積乱雲群 に対して，収束雲（岡林・里見，1971等）あるい はV字型（内田，1980，1982），トランスバース 雲列（八木・内山，1980）など種々な雲のシステ ムに関する解析例が報告されている。植村(1980)

(a) 25 FEB. 1981 Daily precipitation amount $(\mathrm{mm})$

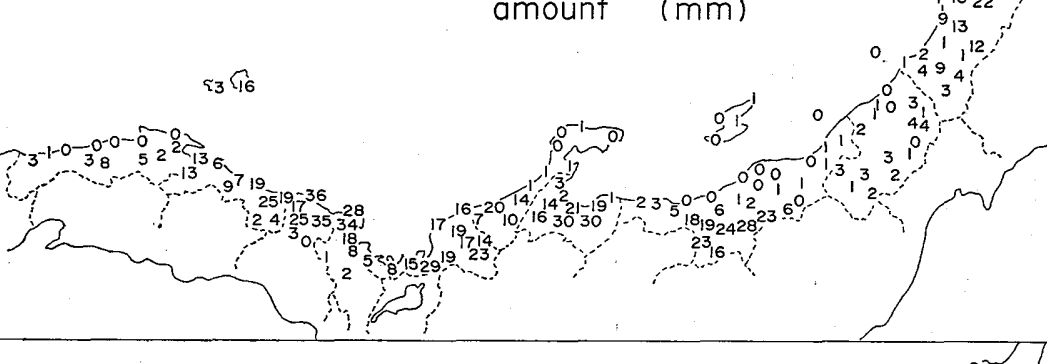

(b) 26 FEB.

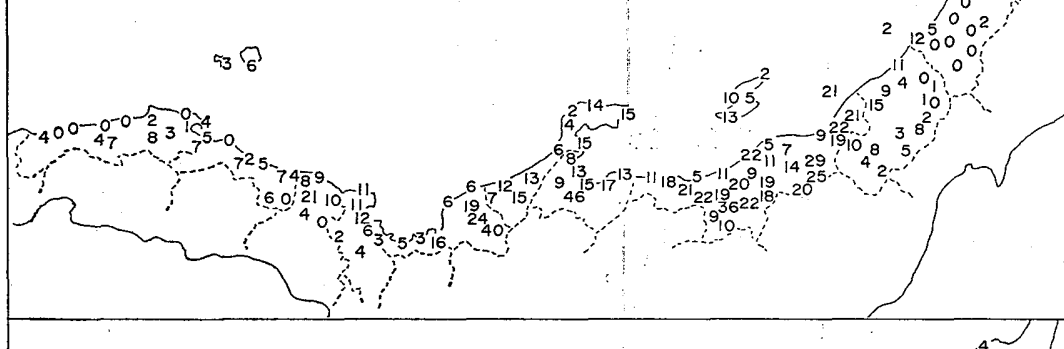

(c) 27 FEB.

$\approx 2 \sqrt{2}$

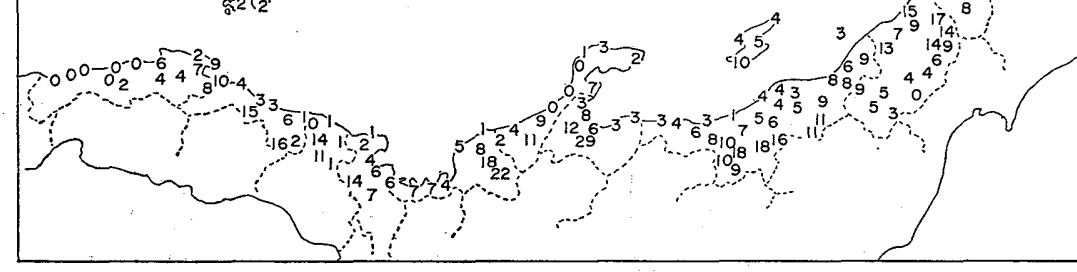

Fig. 15 The distributions of daily precipitation amount.

(a) 25 th. Feb. 1981

(b) 26 th.

(c) 27 th. 

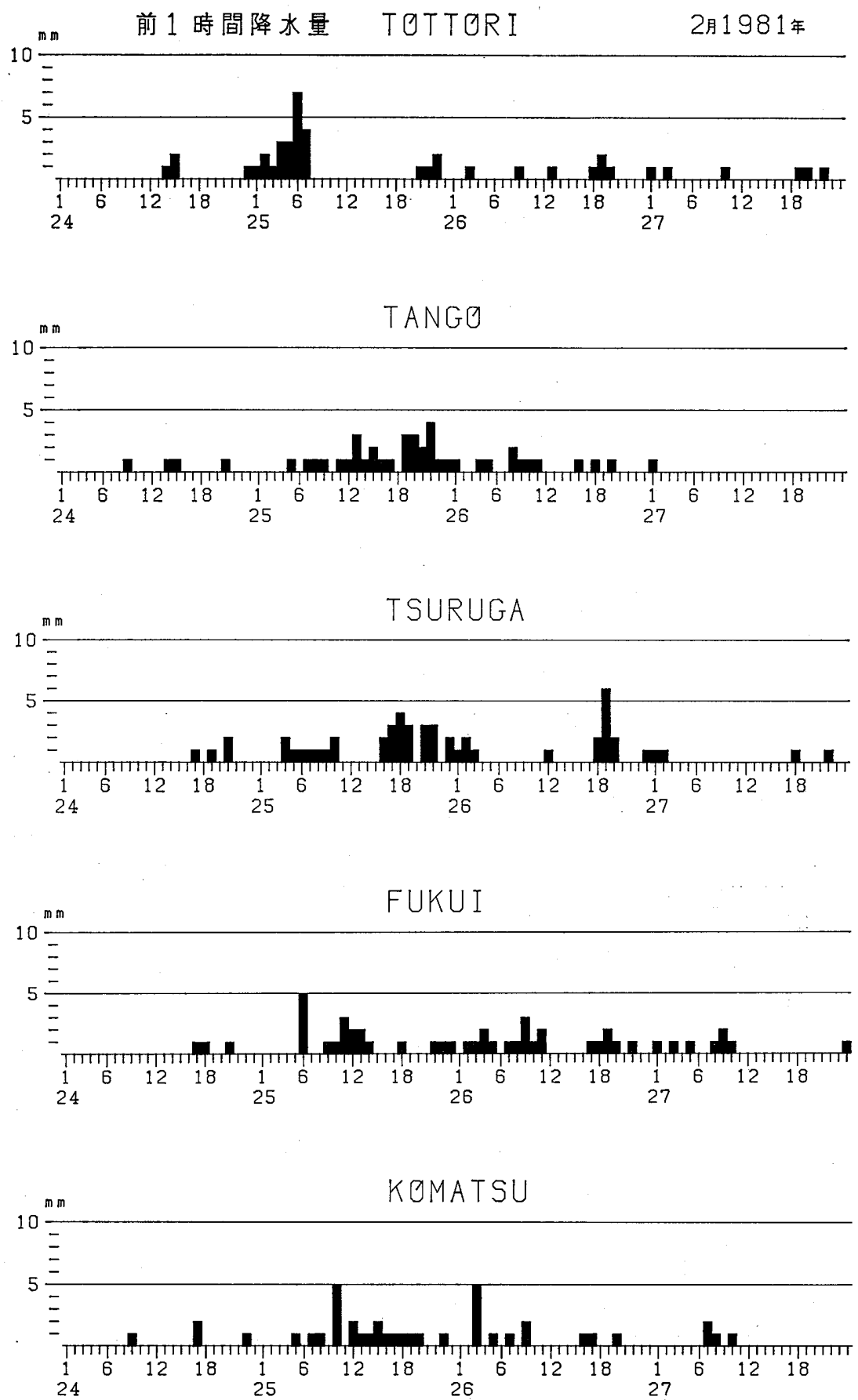

Fig. 16 The hourly precipitation amount at Tottori, Tango, Tsuruga, Fukui and Komatsu. 
は強い降雪を起したらず状の雲やそれに伴なら小 低気圧の発達過程や構造についての解析例を報告 している。

また，豪雪時のスケールの小さい諸擾乱の解析 や研究が多数行われてきた (Matsumoto et al, 1965; Matsumoto - Ninomiya - Akiyama, 1967• $\mathrm{a} \cdot \mathrm{b}$; Miyazawa, 1967; 松本，1968等)。

ここでは, 極気低気圧に伴なら発達した対流雲 バンド系と, 日本海沿岸に和ける降雪量分布との 関連性について，アメダス資料を用いて調べた。

(a) 日雨量分布をみると，第15図 a に見られる ように，2月25日には，鳥取県から福井県にかけ て, 20〜30 mm といら大雪が降っていた。この 大雪域は26日に新潟県に移り，27日に秋田県の本 荘付近に移動した(第15図 b , c )。

(b) 衛星写真（第 4，5図）と比較してみれ ば，これらの大雪域は，小低気圧 2 に伴なわれて いる発達した積乱雲群を含んでいる対流雲バンド によるものであることがわかる。 (c) 上に述べてきたように，平野部豪雪は，極 気低気圧に伴なら発達積雲群やコンマ型, あるい はスパイラル型の対流雲バンドが平野部にかかっ たとき生じていることを示した。このことは， 1977年 2 月 15日，1978年 2 月16～17日の解析例に ついても見られた。1.976年11月28日の例では, 最 大日雨量 $40 \mathrm{~mm}$ に達する平野部の時雨が, 同様 な状態で見られた(竹内・内山，1979）。

(d) 第16図に同じ日降水量が多い領域に属して いる鳥取, 丹後, 敦賀, 福井, 小松と, 第17図に は, 寺泊, 粟島, 村上の前 1 時間降水量の時間的 経過を示した。小低気压の移動に伴なって降水域 の時間的移動がわかる。地形の影響も考慮しなけ ればならないが，組織化された同一の雲バンドの 中にめっても，1時間降水量の時間経過は違って 扮り，1時間降水量分布はさらに細かい対流雲バ ンド内のスケールの小さい擾乱によって左右され ていることがうかが光る。

既に見てきたように，日本海に上層の寒冷渦も
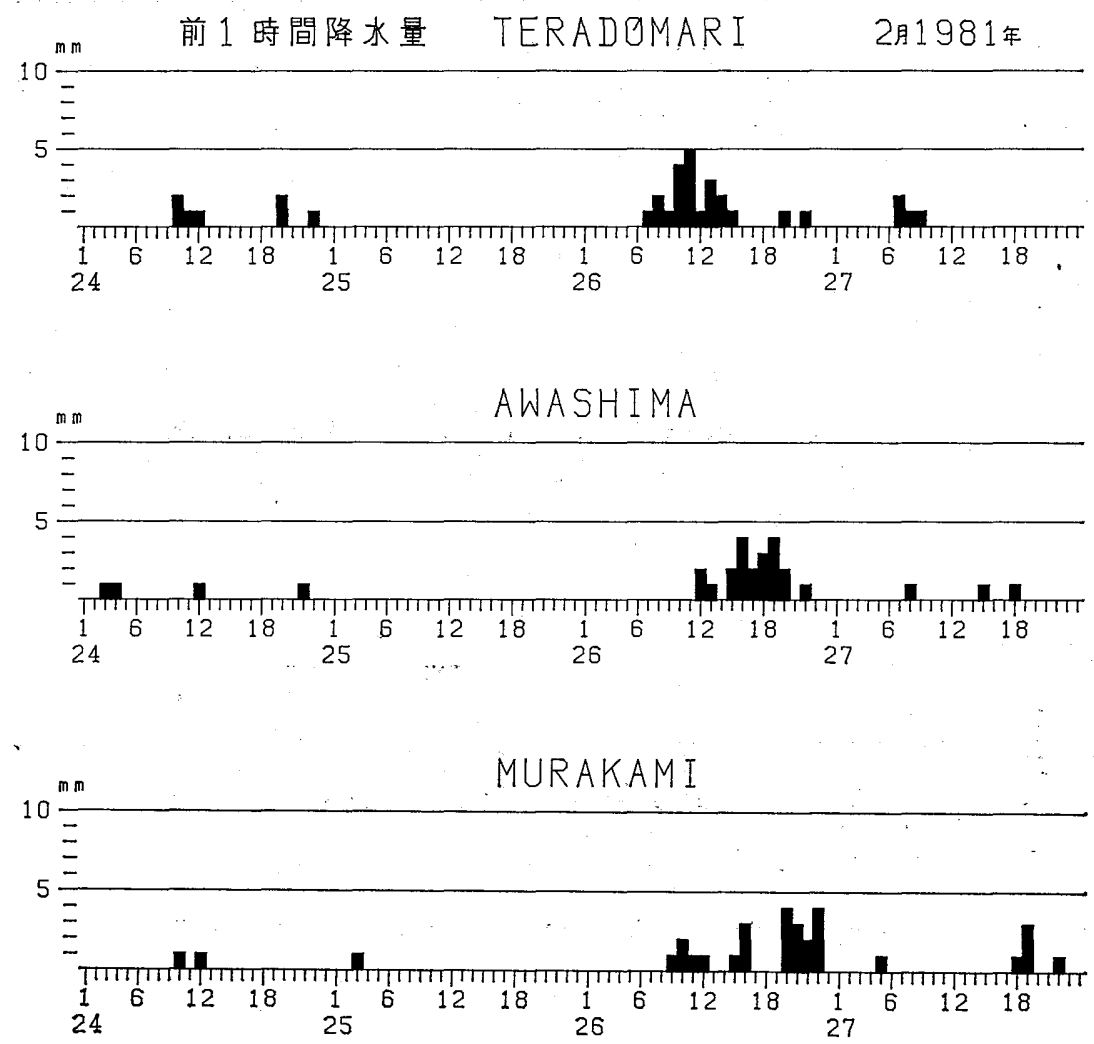

Fig. 17 Same as Fig. 16, but at Teradomari. Awashima and Murakami. 
しくは正渦度の極大を示すような弱いトラフが存 在するときには，日本海に小低気圧が形成され る。このような極気低気圧の周辺は, 深い対流的 に中立な成層状態が存在し，そこには，冬期にし ては発達した背の高い積乱雲群があり，これは同 時に日雨量の豪雪域になっていたことが示されて いる。

\section{7. 結 論}

日本海に打ける寒気団中の, 大きさが $1000 \mathrm{~km}$ 程度以下の極気低気圧 6 例について解析を行った 結果を, 主として1981年 2 月 24 日〜27日の 2 例に よって記述した。次のような結論が得られてい る。

（1）日本海では，冬期，全くの寒気団の中で, $500 \mathrm{mb}$ の正渦度極大域の前面に, 地表面で非前 線性の小低気圧あるいはトラフが形成される。そ の雲系は主として対流雲で構成されている。この 地表面の低気圧あるいはトラフはスケールが小さ く，極気低気圧あるいは極気谷とみなせる。この 場合の $500 \mathrm{mb}$ 面の正渦度極大域には, $500 \mathrm{mb}$ 面の寒気核をもった低気压あるいは寒冷渦に一致 するものと, マイナートラフに一致するものと 2 種類あった。

（2）極気低気圧のひとつの特徵である，背の高 い対流的に中立な層の形成について調べた。乾燥 断熱変化の仮定のもとに, 安定度変化の式を用い て，主として 700～500 mb の層の安定度の変化 を調べた。正渦度極大域の前面では，水平の収束 場によって気層が不安定化され，後面では水平の 発散場のために, 気層が安定化されている。日本 海上の寒気団では冬期 $700 \mathrm{mb}$ 以下の下層では, 海面からの加熱によって対流的に中立な層が形成 されているので, 正渦度極大の前面では, 地表面 から 5 6 km 以上に及ぶかなり深い層の対流的 に中立な層が形成されていることが示されてい る。

これらの対流的に中立な層には，冬期としては 比較的背の高い, $5 \sim 6 \mathrm{~km}$ 以上の 雲項高度を持 っている対流雲が形成され，極気低気圧の特徵と して知られている発達積雲群から, 最盛期にはコ ンマ型あるいはスパイラル型の雲系に組織化され ている。寒冷渦に伴ならものは, 従来から知られ ているように, 最盛期にはスパイラル型を示した
が、そうでないものもスパイラル型に発達したも のが 1 例あった。

(3) これらの小低気圧の形成を, Petterssen の 発達式を用いて調べた。その結果，上層の正渦度 極大域の前面の正渦度移流項特よび非断熱加熱項 が，地表面の低気仕の発達に対して，卓越した寄 与をしていることが示された。また，これらの小 低気圧形成域では，Richardson 数が 10以下の小 さい值を示していた。岸保执よび時岡の理論によ れば，一般場が傾圧性をもち，凝結の潜熱の放出 が大きく， Richardson 数が10程度と小さい場で は, $1000 \mathrm{~km}$ 程度の大きさの不安定擾乱が存在 し得るとされている。ここでの解析結果では, 非 断熱加熱項が対流活動が大きい部分で大きかった こと, 及び, 正渦度移流項は傾圧大気で大きいこ とから，スケールの小さい極気低気压の形成は, これらの理論で説明されることが示唆されてい る。

（4）日本海沿岸地方に和ける平野部豪雪の場合 の日降水量の多い領域は, 極気低気圧に伴なら発 達した対流雲バンドに覆われていることが示され ている。

\section{謝辞}

本研究に対して貴重な御意見及び議論を戴いた 気象研究所予報研究部の方々, また同研究部山崎 孝治氏及び本論文のレフリ一の方々に深謝しま す。

\section{参考文 献}

Anderson, R.K., J.P. Ashman, G. R. Farr, E. W. Ferguson, N. Isayeva, V. J. Oliver, F. C. Parmenter, T.P. Popova, R.W. Skidmore, A. H. Smith and N. S. Veltishchev, 1973: The use of satellite pictures in weather analysis and forecasting. W.M.O. Technical Note, No 124. pp. 275.

Brunt, D., 1939: Physical and dynamical meteorology. 2nd ed. University Press, Cambridge, Eng. pp. 428.

Duncan, C.N., 1977: A numerical investigation of polar lows. Quart. J. Roy. Meteor. Soc., 103, 255-268.

Eady, E.T., 1949 : Long waves and cyclone waves, Tellus, 1, 33-52.

Fukuda, K., 1965: Synoptic study on the mechanism of heavy snowfall. Geophys. Mag., 32, 
317-359.

Fukuda, K., 1966: A synoptic study on the heavy snowfall in the Japan-Sea coastal area of the Hokuriku Distridt. J. Met. Soc. Japan, Ser. II, 44, 201-208.

Gambo, K., 1970 a: The characteristic feature of medium-scale disturbances in the atmosphere (I). J. Met. Soc. Japan, ser. II, 48, 163-184.

Gambo, K., 1970 b: The characteristic feature of medium-scale disturbances in the atmosphere (II). J. Met. Soc. Japan, ser. II, 48, 315-330.

Harrold, T. W. and K. A. Browning, 1969: The polar low as a baroclinic disturbance. Quart. J. Roy. Meteor. Soc., 95, 710-723.

Hsieh, Yi-Ping, 1949: An investigation of a selected cold vortex over North America. Journ. of Met., 6, 401-410.

Huschke, R.E, 1959: Glossary of meteorology. Amer. Met. Soc., Boston, Massachusetts, USA, pp. 638.

Mansfield, D.A., 1974: Polar lows: The development of baroclinic disturbances in cold air outbreaks. Quart. J. Roy. Meteor. Soc., 100, 541-554.

Matsumoto, S., T. Asai, K. Ninomiya, M. Iida and M. Takeuchi, 1965: Behavior of the extraordinary cold vortex over the Far East coastal area observed during the period from 22 January to 24 January, 1963. J. Met. Soc. Japan, 43, 100-115.

Matsumoto, S., K. Ninomiya and T. Akiyama, 1967 a: A synoptic and dynamic study on the three dimensional structure of mesoscale disturbances observed in the vicinity of a cold vortex center. J. Met. Soc. Japan, Ser. II, 45, $64-82$.

Matsumoto, S., K. Ninomiya and T. Akiyama, $1967 \mathrm{~b}$ : Cumulus activities in relation to the mesoscale convergence field. J. Met. Soc. Japan, Ser. II, 45, 292-305.

\$kland, H., 1977: On the intensification of smallscale cyclones formed in very cold air masses heated over the ocean. Inst. Rep. Ser. No. 26,
Institutt for Geofysikk Universitet i Oslo, pp. 25.

Palmén, E., 1951: The aerology of extratropical disturbances. Compendium of Meteorology, Amer. Met. Soc. Boston, USA, 599-620.

Petterssen, S., 1956: Weather analysis and forecasting. 2nd ed., Vol. 1, McGraw-Hill. New York, USA, pp. 428.

Rasmussen, E., 1979: The polar low as an extratropical CISK disturbance. Quart. J. Roy. Meteor. Soc., 105, 531-549.

Reed, R.J., 1979 : Cyclogenesis in polar air streams. Month. Wea. Rev., 107, 38-52.

Stevenson, C.M., 1968: The snowfalls of early December 1967. Weather, 23, 156-162.

Tokioka, T., 1973: A stability study of mediumscale disturbances with inclusion of convective effects. J. Met. Soc. Japan, Ser. II, 51, 1-10.

Yagi, S. and T. Uchiyama, 1980: Analysis of large-scale cloud pattern with transverse mode and consideration on mechanism of its formation. Extended abstracts, Tech. Conf. C.A.W. P.A., Guangzhou 15-20, Dec. 1980, 57-60.

福田喜代志, $1968 \mathrm{a}$ : 総観場の統計的解析. 気象庁技 術報告66号，44-51.

福田喜代志, $1968 \mathrm{~b}$ ：総観モデル．気象庁技術報告66 号, 432-438.

倉嶋厚, 1968 ：上空寒気 と降雪. 気象庁技術報告 66 号, 52-60.

松本誠一, 1968 : 北陸豪雪の総観モデル. 気象庁技術 報告66号，442-449.

岡林俊雄, 里見穂, 1971 : レーダーと気象衛星による 雪雲の研究 ( I ). 天気, 18,573-581.

竹内衛夫, 内山徳栄, 1979 : しぐれと総観現象との関 連についての諸問題. 気象打技術報告97号, 221238.

植村八郎, 1980 : 冬期季節風下の日本海沿岸に大雪を もたらすじょう乱の構造と形成について。.天気， 27, 33-44.

内田英治, 1979 : V字型の雲パタンと日本海沿岸の大 雪. 天気, 26, 287-298.

内田英治, 1982 : V字型の雲パタンと日本海沿岸の大 雪 (II). 天気, 29, 43-52. 


\title{
日本海における極気低気圧およびそれに伴う沿岸平野部豪雪の解析
}

\author{
竹内 衛夫* • 内山 德栄
}

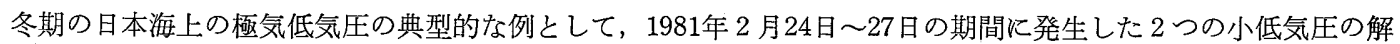
析が述べられている。

この報告では，次のような結果が得られている。

（1）冬期の日本海上では，全くの寒気団の中でスケールの小さい非前線性の低気圧が形成される。これらの低気 压は, $500 \mathrm{mb}$ 面の正渦度極大の東側に位置し, 最盛期には対流雲から成っているスパイラルあるいはュンマ 型の雲パターンを伴なっている。またかなり厚い深さの対流的に中立な層を伴ない, ジェット気流の極側の対 流圈全体に及ぶような偏西風帯の傾圧性をもった領域に位置している。これらの特徴は, これらの低気圧がい わゆる極気低気圧であることを示している。

(2) $500 \mathrm{mb}$ 面の正渦度の極大には 2 種類ある。1つは寒冷渦の中央部分に位置して扣り，むらひとつはトラフ 領域に位置している。日本海上では上層の寒冷渦に結びついて発生した地表面低気圧もまた約 $1000 \mathrm{~km}$ 程度 以下の小さいスケールであり，極気低気圧とみなされる。

（3）対流的に中立な深い層の形成について調べた。安定度変化の式によって，500 mb 面の正渦度極大の前面 で，700 500 mb の間の対流圈中層の対流的に中立な層は，主に水平の収束の効果によって形成され，一方 これらの後面領域では，対流圈中層が水平の発散の効果によって安定化されることが示されている。700 mb 以下の層は，冬期の海洋上の低層加熱によって不安定化されていると考えられるので，上下の不安定化された 層が結合して，上層の正渦度極大の前面で，対流圈の相当な深さを通じての 対流的に中立な層を形成してい る。

（4）これらの低気圧の形成のための不安定化の機構がペターセンの発達式及びリチャードソン数の分布を用いて 議論されている。地表面の低気圧形成に対する上層の渦度移動の影響を含んでいる傾圧性の効果, および10以 下の小さいリチャードソン数の大気中での非断熱効果が, 約 $1000 \mathrm{~km}$ 程度以下の小さい低気圧形成の主因で あることが示唆されている。

（5）日本海沿岸地方の極気低気圧に伴なら対流雲バンドに起因する平野部豪雪が調べられている。日降水量分布 は，これらの対流雲バンドの分布によって説明され得ることが示されている。

* 現在 山形地方気象台 